\title{
Systematics, biostratigraphy and significance of discoid and partly discoid corals from the Devonian of northwestern Canada, Ural Mountains Russia and southeastern Australia
}

\author{
Alan E.H. Pedder
}

\begin{abstract}
Subfamily Microcyclinae Plusquellec, 2006 is promoted to family rank. A new family, genus and species, Devonodiscidae, Devonodiscus and D. latisubex are named. Combophyllum multiradiatum Meek, 1868, which is based on a specimen from an unknown Mackenzie Valley location and formation, is assigned to Devonodiscus and redescribed using specimens from accurately known formations and locations. Glossophyllum discoideum Soshkina, 1936, from the Eifelian of the Ural Mountains, is also assigned to Devonodiscus. Six other species, previously placed in either Combophyllum, Palaeocyclus, Microcyclus, Hadrophyllum or Chonophyllum, may belong to Devonodiscus. New topotypic material of one of these, Hadrophyllum wellingtonense Packham, 1954 is illustrated. In late ontogeny Devonodiscus latisubex and D. discoideum (Soshkina) commonly modified their corallum to become cylindrical with a cystiphylloid-like interior. Glossophyllum discoideum may regain a discoid morphology, making the corallum pulley-shaped. Such changes were probably caused by disruptions to bedding surfaces on which the corals developed. An unrelated coral, originally named Actinocystis versiformis is discoid becoming cylindrical after disruptions caused by increased water-depth. New specimens from the type locality in the central Western Urals are described and illustrated as Digonophyllum versiforme (Markov, 1923). The species' complicated taxonomy and synonymy are attempted. High resolution stratigraphy indicates Devonodiscus multiradiatus to be confined to the middle Eifelian Eoschuchertella adoceta benthic assemblage and australis conodont zones, and D. latisubex to the late Eifelian upper Carinatrypa dysmorphostrota benthic assemblage and upper kockelianus conodont zones. Canadian discoid corals add further evidence that northwestern continental Canada and Northern Urals belonged to the same faunal province in late Eifelian time. $•$ Key words: Devonian, discoid corals, Canada, Urals, Australia, biostratigraphy, palaeozoogeography.
\end{abstract}

PedDER, A.E.H. 2019. Systematics, biostratigraphy and significance of discoid and partly discoid corals from the Devonian of northwestern Canada, Ural Mountains Russia and southeastern Australia. Bulletin of Geosciences 94(2), 137-168 (10 figures, appendix). Czech Geological Survey, Prague. ISSN 1214-1119. Manuscript received November 9, 2018; accepted in revised form March 21, 2019; published online June 17, 2019; issued June 17, 2019.

Alan E.H. Pedder, previously Geological Survey of Canada, emeritus; presently 8859 Park Pacific Terrace, Sidney, B.C., Canada,V8L4S1; apedder@telus.net

Two discoid or button-shaped coral species from the "Hamilton group" of the region of Mackenzie River and Porcupine River Russian America, were named and briefly described by Meek in 1868. Their collection before that date in remote land-locked areas inevitably means that the localities provided could only have been very approximate. Both species were based on a single specimen and placed in the Museum of the Smithsonian Institution, now the United States National Museum. The specimen from Alaska, named Palaeocyclus kirbyi is lost (Bassler 1937, p. 190). Since no additional material is available the species is mentioned in the present work only as a questionable synonym of Meek's other 1868 species. The holotype of Meek's second discoid coral, named Combophyllum multiradiatum, is extant but is severely water-warn and is from an unknown formation and locality. With access to about 20 collections containing C. multiradiatum, some from carefully measured stratigraphic sections, it has been possible to re-interpret the litho- as well as the biostratigraphy of $C$. multiradiatum. More than a hundred specimens of the species have been identified, providing new data on its variable morphology. Although the family and genus status have changed, no formal taxonomic treatment has become available since the species was proposed one and a half-centuries ago. Published comments are restricted to Bassler's comments that the holotype is a water-worn circular disc, $18 \mathrm{~mm}$ wide, about $3 \mathrm{~mm}$ thick and that it belongs to Microcyclus, and McLaren's observation (1962, p. 12) that longitudinal sections of the species show it to be correctly identified with the Hadrophyllidae. After discussion of the Hadrophyllidae the present work raises one of its previously constituent sub- 
families, the Microcyclinae, to family rank, and establishes a new family and genus for $C$. multiradiatum, named Devonodiscidae and Devonodiscus. Microcyclus Meek \& Worthen and Crassicyclus Soto are included in the Microcyclidae.

The new genus Devonodicus is possibly represented in the Lower Devonian of eastern Australia, northern Vietnam, Southern Yunnan and the Taimyr Peninsula of Russia. It certainly occurs in the Eifelian of the northwestern North American Craton and the Western Ural Mountains of Russia. At least two species of Devonodiscus, including the newly named $D$. latisubex, from northwestern Canada, normally began life in low energy, variably anoxic facies. If individuals remained undisturbed, they retained simple or only slightly rejuvenated discoid coralla with little change in corallite height or diameter. However if disturbed to threaten vertical growth, the morphology of the corallum, septal and horizontal skeletal elements were all changed to allow vertical growth to continue. Parts of sections through a corallum of Devonodiscus that underwent a change of life direction resemble sections of most cystimorph species, including Actinocystis vermiformis Markov, 1923. Markov believed that the morphology of $A$. vermiformis changed according to the environment in which it lived, very much like that of some species of Devonodiscus. Presence of probable topotypes of Markov's species in the Geological Survey of Canada's collections allows a contribution to its problematic taxonomy. Here it is referred to the genus Digonophyllum in the family Digonophyllidae.

\section{Geological formations providing new discoid corals}

Stratigraphic units that have provided the new material described herein are the Hume and Headless formations on the northwestern Canadian Craton, and the Garra Formation on the Molong-Monaro Terrane of southeastern Australia.

The Hume Formation was proposed by Bassett (1961, pp. 486-489) for a mappable unit of fossiliferous limestones and shales exposed in the Mackenzie Mountains, central Mackenzie River Valley region and on the Anderson Plain. Previously a subsurface section pene trated by Discovery Well No. 3 of the Norman Wells Oilfield had been designated the type section of a unit named the Norman Wells formation by Crickmay (1960b, p. 877 footnote). Crickmay's unit is the same as Bassett's Hume Formation. However, subsequent workers have followed Caldwell's (1964, p. 615) reasoning for using Bassett's rather than Crickmay's formational name. Uyeno (1978) and Uyeno et al. (2017) have shown the formation to be Eifelian, upper Tortodus australis and T. kockelianus conodont zones.
The name Headless Formation was introduced by Douglas \& Norris (1961, p. 19) for map unit 21 of their 1960 paper. A type section was neither designated nor shown on their maps. However, the name Headless and the statement that a section in the vicinity of Headless Range, on the second tributary from the east of Meilleur Creek, was one of two typical sections of the formation, is here taken to indicate that this should be regarded as the type section. There is no evidence that it was measured carefully or collected for fossils, nevertheless a thickness of 560 feet $(170.7 \mathrm{~m})$ was given. The upper 150 feet $(45.7 \mathrm{~m})$ with resistant limestones is probably the lower regressive unit of the Nahanni Formation (Noble \& Ferguson 1971, figs 8,9 ). The Headless Formation is widely distributed in southwestern Northwest Territories, including an area south of the area shown in Fig. 1. It passes laterally into the generally shallower water facies of the Hume Formation to the north and east (Pedder 2017, text-fig. 2) and into shallower facies of the Nahanni Formation to the south and east (Chatterton 1978, fig. 3). Biostratigraphic data concerning the Headless Formation at its assumed type area comes from two sections (approximately $61^{\circ}$ $12^{\prime} \mathrm{N} 143^{\circ} 43^{\prime} \mathrm{W} ; 61^{\circ} 41.5^{\prime} \mathrm{N} 124^{\circ} 38.5^{\prime} \mathrm{W}$ ) studied by members of Triad Oil Co., including the present author, in 1960. These are virtually the same as sections 2 and 3 of Noble \& Ferguson (1971, figs 8, 9). Triad's thicknesses for the Headless Formation at these localities are $95.2 \mathrm{~m}$ and $60.6 \mathrm{~m}$. Faunas of the Headless and Hume are similar, both contain the significant conodonts Steptotaxis pedderi, previously Pelekysgnathus pedderi, and Polygnathus curtigladius, which indicate upper Eifelian Tortodus kockelianus and at least part of the underlying T. australis conodont zones (Chatterton 1978, Uyeno 1978, Uyeno et al. 2017). Differences between the two faunas include the much more common occurrences of Warrenella species and pelecypods such as Paracyclas in the Headless faunas (Ludvigsen \& Perry 1975, Pedder unpublished data).

The Garra Formation, first mentioned as Garra Beds by Joplin \& Culey (1938), was formally defined as a formation by Strusz (1965, pp. 85-88). The type section, shown on Strusz's figure 1, consists of c. 4000 feet $(1219 \mathrm{~m})$ of "interbedded and intertonging clastic limestones, biostromal limestones, and bioherms". Talent \& Mawson (1999, p. 52) described the Garra Limestone as ">1060 m; predominantly richly fossiliferous shoalwater limestones". However, stratigraphic thicknesses of the Garra Formation in the northernmost and southernmost outcrops are certainly much less. Exposures of the formation are confined to an elongate area in east-central New South Wales, stretching from near Geurie southwards for almost $100 \mathrm{~km}$ to Cudal, with a thin southern tongue extending westward into the lower Mandagery Park Formation (Mawson et al. 1989, fig. 5; Talent et al. 2001, 


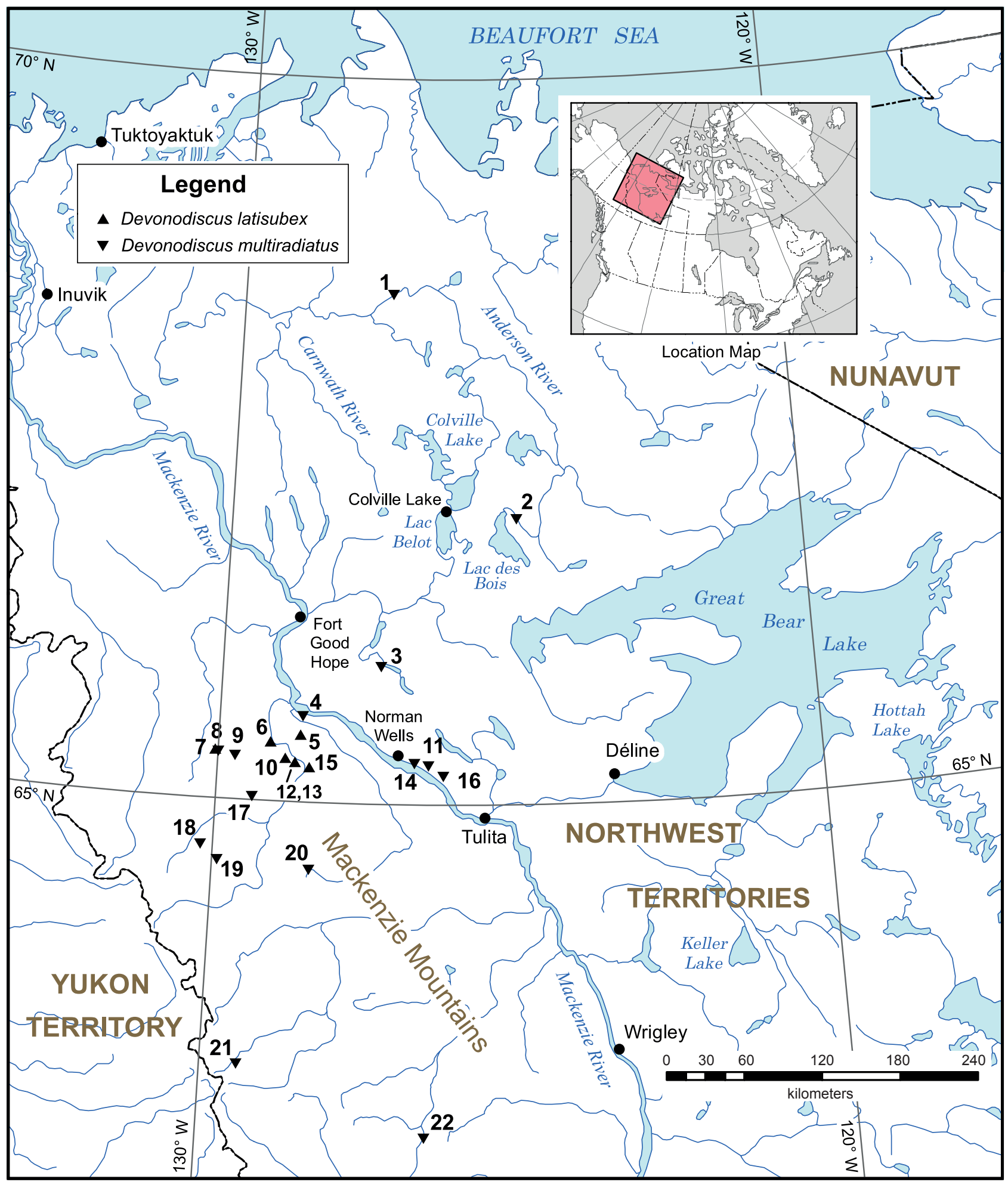

Figure 1. Map with 22 localities that have yielded Devonodiscus latisubex gen. et sp. nov. or D. multiradiatus (Meek), plotted in north to south order according to the collectors' estimated co-ordinates. Localities 7 with D. latisubex and 8 with D. multiradiatus are almost the same locality, so that on a map of this scale their symbols become superposed. See Appendix for stratigraphic data. Abbreviations of localities: 1 - Triad D15; 2 - "Onion River" Meek, 1868 locality; 3 - C-002536; 4 - O-007235; 5 - C-083491; 6 - C-025838; 7 - C-024674; 8 - C-024631; 9 - O-040357; 10 - C-025839 \& C-025840; $11-$ C-001804; 12 - C-012174, C-012175 \& C-049662; 13 - C-003871 \& C-003872; 14 - C-001800; 15 - C-049669 \& C-049670; 16 - C-012116; 17 - C-075743; 18 - C-075555; 19 - C-75538 \& C-075539; 20 - C-003959; 21 - O-058761; 22 - O-058665. 
fig. 6). For conodont ages the most intensely studied areas of the Garra Formation are around Wellington Golf Course (especially Mawson et al. 1989, Wilson 1989), Eurimbla (Sorentino 1989), The Gap (Farrell 1992, 2003) and Manildra (Trotter \& Talent 2005). These studies show the formation to be diachronous. In the southern outcrops at Eurimbla, The Gap and the Mandagery outlier, the lowermost beds belong to the middle Lochkovian Ancyrodelloides delta Zone. At the more northern Wellington Golf Course and Geurie areas the lowermost beds of the formation are upper Lochkovian Pedavis pesavis Zone. Diachronism of the uppermost original Garra Formation is difficult to assess because of the major disconformity that eliminates most of the Eifelian, Givetian and earliest Frasnian from the Garra outcrop area. Nevertheless, the present author accepts that the uppermost beds of the Garra Formation in the southern outcrops are no younger than middle Pragian Eognathodus kindlei Zone (as used by House \& Gradstein 2004), whereas the youngest beds of the formation exposed near Wellington Golf Course are at least as young as the upper Pragian Polygnathus pireneae Zone.

\section{Lithostratigraphy and biostratigraphy}

The new genus and species Devonodiscus latisubex occurs exclusively in deeper water facies of the upper Carinatrypa dysmorphostrota benthic assemblage Zone of the Hume Formation. Ranges of D. latisubex, determined from careful collecting and given as stratigraphic thickness below top of the Hume Formation are as follows: 0-6.0 m at Imperial Hills (loc. 5 on Fig. 1), 0-2.4 m at Gayna River Gorge (loc. 6 on Fig. 1), 0.6-4.3 m at type section of Hume Formation (loc. 7 on Fig. 1), 4.3-7.3 m at Bell Creek (loc. 10 on Fig. 1), 2.4-9.5 m at Powell Creek and nearby tributary (loc. 12, 13 on Fig. 1) and $5.1-7.4 \mathrm{~m}$ at Mountain River (loc. 15 on Fig. 1).

Typical species of the Carinatrypa dysmorphostrota benthic assemblage Zone that have been collected with Devonodiscus latisubex are corals Digonophyllum rectum (Meek), D. powellense McLean, Chostophyllum coniculus Pedder, and brachiopods Spinulicosta stainbrooki Crickmay, Variatrypa arctica (Warren), Isospinatrypa borealis (Warren) and Carinatrypa dysmorphostrota (Crickmay). Less common species of the assemblage that can be identified to species level and have been collected with Devonodiscus latisubex are corals Neozonophyllum petilum (McLean), Nardophyllum macrocystis (Schlüter), N. pumilum (McLean), Microplasma caespitosum (Schlüter), Chostophyllum humense Pedder, Houershanophyllum mcfarlanei (Meek), Sociophyllum glomerulatum (Crickmay), brachiopods Spinatrypa andersonensis (Warren), S. coriacea (Crickmay), Undispirifer compactus (Meek), and trilobites Camsellia truncata Ormiston, Fuscinipyge yolkini Ormiston and Humeia merga Ormiston. Coral genera prominent in shallow facies of the dysmorphostrota assemblage Zone, such as Dendrostella, Utaratuia, Gansuastraea and Taimyrophyllum are absent from faunas containing D. latisubex.

All but two of the known occurrences of Devonodiscus multiradiatus (Meek) are in the Eoschuchertella adoceta benthic assemblage Zone of the lower Hume Formation. The two that are not are in the same assemblage zone in the Headless Formation. Lithostratigraphy of the Hume Formation occurrences, expressed as thickness above base of the formation are: $16.7-21.3 \mathrm{~m}$ at the southwest side of Sam MacRae Lake (loc. 3 on Fig. 1), 15.2-17.7 $\mathrm{m}$ at type section of the Hume Formation (loc. 8 on Fig. 1), 23.2-25.9 m at a tributary of Gayna River (loc. 9 on Fig. 1), $<7.6 \mathrm{~m}$ at Canyon Creek (loc. 11 on Fig. 1), $10.7 \mathrm{~m}$ at Bosworth Creek (loc. 14 on Fig. 1), 19.5-25.6m at west fork of Prohibition Creek (loc. 16, on Fig. 1), $13.5 \mathrm{~m}$ at southwest of Drainpipe Lake (loc. 17 on fig. 1), $27.5 \mathrm{~m}$ at North Eduni 1 section (loc. 19 on Fig. 1), $25.3 \mathrm{~m}$ at Tern Creek Section (loc. 20 on Fig. 1). The two known occurrences of the species in the diachronous Headless Formation, expressed as thickness above base of the formation are $7.6 \mathrm{~m}$ northeast of Dal Lake (loc. 21 on Fig. 1) where the formation is $163.1 \mathrm{~m}$ thick, and $83.9 \mathrm{~m}$ on a ridge northwest of Thundercloud Range (loc. 22 on Fig. 1) where the formation is $295.7 \mathrm{~m}$ thick.

Additional species in the Eoschuchertella adoceta-bearing faunas of the lower Hume Formation are a species of Gansuastraea (illustrated Pedder 2017, text-fig. 4d, e), Pseudodohmophyllum mutabile (Pedder), both corals, and brachiopods Spinulicosta stainbrooki Crickmay, Independatrypa aperanta (Crickmay) and Undispirifer compactus (Meek). Single occurrences of the following species occur with D. multiradiatus in the Hume Formation: corals Microplasma caespitosum (Schlüter) small form, Digonophyllum rectum (Meek), Lekanophyllum andersonense McLean, L. mediale McLean, Taimyrophyllum triadorum Pedder, brachiopods Spinatrypa coriacea (Crickmay), Variatrypa arctica (Warren), Spinatrypa andersonensis (Warren), trilobites Fuscinipyge applanata Ormiston, Humeia merga Ormiston and the problematical species Sphaerospongia tessellata sensu Warren (1944). Spinulicosta stainbrooki and Spinatrypa coriacea are the only two species collected with Devonodiscus multiradiatus in the Eoschuchertella adoceta benthic assemblage Zone in the Headless Formation.

\section{Age of northwestern Canadian discoid corals}

The Global Stratotype Section and Point (GSSP) for the Eifelian-Givetian Stage boundary is located at Jebel 
Mech Irdane in Morocco, and placed at the stratigraphic level where the conodont Polygnathus pseudofoliatus evolved into P. hemiansatus (Walliser et al. 1995, Walliser 2000). Thus the Eifelian-Givetian boundary has become a conodont-based boundary. As a result it has not been precisely determined in any of the Devonodiscus latisubex-bearing outcrops in western Canada. The best attempts to establish it in respect to D. latisubex occurrences come from conodont studies at Powell Creek and at the type section of the Hume Formation. At Powell Creek Uyeno (1978, tab. 1, fig. 2) identified a specimen of P. pseudofoliatus from a sample (GSC Loc. C-003873) collected from a $3 \mathrm{~m}$ interval spanning the uppermost Hume and lowermost Hare Indian formations. The lower range of the same conodont species was shown to embrace the upper c. $35 \mathrm{~m}$ of the Hume Formation. At the type section of the Hume Formation, Uyeno (in Uyeno et al. 2017, text-fig. 3) has shown the range of $P$. pseudofoliatus to be at least $32 \mathrm{~m}$ below top of the Hume Formation to $3 \mathrm{~m}$ above base of the overlying Hare Indian Formation. Furthermore, specimens in the uppermost $2.1 \mathrm{~m}$ of the type section of the Hume Formation are transitional to P. hemiansatus Uyeno in Uyeno et al. (2017, p. 394). From these data, $D$. latisubex certainly occurs in the upper Eifelian Polygnathus kockelianus conodont Zone, and may just extend into the uppermost Eifelian xylus ensensis conodont Zone of House \& Gradstein (2004, p. 210).

The conodont Steptotaxis pedderi, erected by Uyeno \& Mason (1975) as a species of Pelekesgnathus, occurs with abundant Devonodiscus multiradiatus and Eoschuchertella adoceta $54.9-59.4 \mathrm{~m}$ below top of an incomplete exposure of the Hume Formation near Sam MacRae Lake (loc. 3, Fig. 1). The same conodont species has been identified by Uyeno (1978, p. 237, fig. 2) $15.2 \mathrm{~m}$ above the current base of the Hume Formation at Powell Creek (loc. 13, Fig. 1), and in three samples (Uyeno et al. 2017, p. 397) ranging 5.9-14.5 $\mathrm{m}$ above base of the Hume Formation at its type locality (loc. 8, Fig. 1). These last localities have not yielded $D$. multiradiatus but are certainly in the $E$. adoceta benthic assemblage Zone. The significance of $S$. pedderi is that it is likely confined to the middle Eifelian Tortodus australis conodont Zone, recognised by Klapper \& Johnson (1980, p. 422) and House \& Gradstein (2004, p. 210).

\section{Palaeozoogeographical significance}

Blodgett \& Pedder (2018) outlined faunal similarities in late Eifelian time between northwestern Canada including Anderson Plain and the US Midcontinent, based on brachiopods Spinulicosta stainbrooki, Helaspis sp., Variatrypa arctica, Isospinatrypa borealis and Carinatrypa dysmorphostrota. The main purpose of Blodgett and
Pedder's paper was to publish a new occurrence of the rare gypidulid genus Zdimirella, which is known only from Anderson Plain where it is represented by $Z$. borealis (Meek) and southwestern Novaya Zemlya, immediately north of the Ural Mountains, where it is represented by the very similar Z. kuzmini Cherkesova. Upper Eifelian occurrences of the new genus Devonodiscus in northwestern Canada and western northern Urals are further evidence that the two regions belonged to the same faunal province in late Eifelian time. The probable occurrence of a discoid species of Devonodiscus (Meek's Palaeocyclus kirbyi) in the Salmontrout Limestone at some point along Porcupine River, northeastern Alaska, suggests that elements of the northwest Canadian and northern Ural Eifelian faunas extended to cratonic Alaska. The consistently discoid microcyclid genus Microcyclus Meek \& Worthen, 1868 is not present in faunas that include Devonodiscus. This is as expected because species of Microcyclus are restricted to late Emsian and Eifelian faunas of southwestern Illinois, southeastern Missouri, Ontario, Eifel Hills of Germany, Cantabrian Mountains of Spain and west of Ougarta, Algeria (Le Maître 1952, Plusquellec 2005).

\section{Systematic Palaeontology}

Repositories. - Coral specimens including primary types and other important Canadian and some Russian material used in this paper are deposited in the Geological Survey of Canada, Ottawa type collection (abbreviated GSC). Specimens originating in NSW, Australia are deposited in the Australian Museum, Sydney, Australia (abbreviated AMFT for thin sections and AMF for the single remnant remaining after preparation). Another repository mentioned is the Senckenberg Museum, Frankfurt, Germany (abbreviated SMF).

Family Digonophyllidae Wedekind, 1923

Remarks. - Originally proposed (Wedekind, 1923, p. 33) as a subfamily of the Cyathophyllidae. Promoted to family rank by Wedekind (1924, p. 12).

\section{Genus Digonophyllum Wedekind, 1923}

1923 Digonophyllum n.; Wedekind, p. 27.

Type species. - Digonophyllum schulzi Wedekind, 1923, p. 27, fig. 1 . This species, which is probably synonymous with Actinocystis pseudoorthoceas Schulz, 1883 (see Birenheide 1964, p. 45), was based on one illustrated transverse section and an unillustrated longitudinal thin section from the same specimen, now reposited as SMF 
$359 \& 360$. Birenheide $(1964$, pp. 82,100$)$ chose this specimen as lectotype, whereas Hill (1981, p. F125) regarded it as the holotype. Occurrence originally given as Digonophyllumstufe, lower Middle Devonian, Nohner Schichten in both the Hillesheimer and Gerolsteiner Muldes. Type occurrence is now more precisely stated (Birenheide 1964; Weddige 1977, p. 364) as lower Nohn Formation, lower Eifelian, costatus conodont Zone, in the Hillesheim Syncline, Eifel Hills, Germany.

Diagnosis. - Corallum solitary, typically trochoid to scolecoid with some rejuvenescences; rare specimens may be discoid in early stages. Major septa (septal crests of McLean 1976) mostly almost or fully complete; minor septa also well developed but commonly incomplete, especially in outer dissepimentarium. Carinae and septal plates absent or rare. Both orders of septa adaxially dilated, typically forming a keyhole fossula in all but earliest stages which however, have not been demonstrated in the type species. Dissepiments small, numerous, normally forming only an ill-defined inwardly sloping calicinal platform. Lateral dissepiments common. Tabulae incomplete, mostly concave and tabelliform, outer tabulae not well differentiated from inner dissepiments.

Remarks. - As previously noted by several authors, including McLean (1976, p. 15) and Lin et al. (1995, p. 153), Digonophyllum is distinguished primarily from other cystimorph genera with long septa by the almost or total absence from it of septal carinae and plates.

\section{Digonophyllum versiforme (Markov, 1923)}

Figure 2A-J

partim 1923 Actinocystis versiformis n.; Markov, p. 35, pl. 6, figs 2, 4, 5, 9, ?text-fig. 1, ?pl. 6, figs 6-12 (non pl. 6, figs 1, 3 = Digonophyllum sp.).

partim 1949 Pseudozonophyllum versiforme (Markov). Soshkina, p. 65, pl. 22, fig. 1a-5, pl. 24, fig. 1 (non pl. 22, figs 6-8 = ? "Glossophyllum" primitivum Soshkina 1949).

1952 Pseudozonophyllum versiforme (Markov). Soshkina, p. 80, pl. 13, fig. 50.

non 1958 Pseudozonophyllum versiforme (Markov). Bul'vanker, p. 54, pl. 18, fig. 1a, b, pl. 19, fig. 1a, b.

non 1960a Pseudozonophyllum versiforme (Markov). Spasskiy, p. 35, pl. 4, figs 3-5, pl. 5, figs 3-5, pl. 6, figs $1,2$.

partim 1960b Pseudozonophyllum versiforme Soshk. - Spasskiy, p. 86 (non p. 92).

?non 1961 Pseudozonophyllum versiforme (Markov). - Zheltonogova \& Ivaniya, p. 396, pl. D-51, fig. 1a, b.

1962 Pseudozonophyllum versiforme (Markov). Soshkina et al., p. 312, tetracoral pl. 5, fig. 1a-v. non 1963 Pseudozonophyllum versiforme (Markov). Kravtsov, p. 34, pl. 12, fig. 2a-g.

partim 1964 Pseudozonophyllum versiforme (Markov). Ermakova, p. 100, pl. 2, figs 5-7. (not synonymy)

1964 Pseudozonophyllum versiforme Mark. - Lyashenko, p. 4.

non 1965 Pseudozonophyllum versiforme (Markov). - Ivaniya, p. 59, pl. 4, fig. 22, pl. 5, fig. 23, pl. 20, figs 90-93, pl. 21, figs 94, 95, pl. 22, fig. 96.

non 1965 Pseudozonophyllum versiforme (Markov). Bul'vanker, p. 54, pl. 13, fig. 2a-g.

non 1968 Pseudozonophyllum versiforme (Markov). - Ulitina, p. 89 , pl. 20, fig. 1a-e.

? 1972 Pseudozonophyllum versiforme (Markov). Tsyganko, p. 32, pl. 3, fig. 3.

? 1975 Pseudozonophyllum versiforme Mark. - Adrianova, p. 233.

non 1975 Pseudozonophyllum versiforme (Markov). Besprozvannykh et al., pp. 11, 17, 102, 109, pl. 42, fig. 1a, b.

1976 Digonophyllum rectum (Meek)? - McLean, pp. 15, 17 (discussion of Markov's 1923, pl. 6, figs 3-5 only).

non 1977 Pseudozonophyllum versiforme (Markov). Spasskiy, pp. 139, 340, pl. 28, fig. 3a, b.

? 1981 Pseudozonophyllum versiforme (Markov). Tsyganko, p. 106, pl. 46, fig. 4a, b.

non 1983 Pseudozonophyllum versiforme (Mark.). - Spasskiy, p. 167.

?non 1985 Pseudozonophyllum versiforme (Mark.). - Elkin et al., pp. 128, 129.

non 1986 Pseudozonophyllum versiforme (Markov). - Ivaniya \& Cherepnina, p. 75, pl. 77, fig. 166a, pl. 78, fig. $166 \mathrm{~b}$.

? 1987 Pseudozonophyllum versiforme (Mark.). - Tsyganko et al., fold-out fig. between pp. 18 \& 19.

1994 Pseudozonophyllum versiforme Mark. - Kozlov \& Dubatolov, p. 21.

? 2011 Digonophyllum versiforme (Mark). - Artyushkova et al., p. 15.

? 2011 Pseudozonophyllum versiforme (Mark.). - Tsyganko, pp. 105, 112, 124.

Type series. - Soshkina (1949, p. 65) stated that the holotype is in the Chernysheva Museum in Leningrad, but did not indicate whether the specimen had been sectioned or illustrated. Markov himself did not designate a type specimen or specimens, but specifically mentioned morphological features of 12 or 13 (depending on whether figures 2 and 10 of his plate are side and calicular views of the same specimen) photographically illustrated specimens. All of the illustrated specimens apparently originated in red oolitic ironstone at the Osinovskiy open pit mine, near the Kus'e Aleksandrov Dacha, central 
western Urals, Russia (Markov, 1923, p. 40). Soshkina $(1949$, p. 66) who had access to at least some of Markov's material in the Chernysheva Museum, gave the occurrence as middle Eifelian, Lotari open pit mine, River Koyva below the Kus'e Aleksandrov Works, Central Urals.

The stratigraphic unit that yielded the type material also yields calceoloid corals, and most subsequent authors recorded the type stratum as Eifelian Calceola beds. Adrianova (1975) and Tsyganko (1981) referred it to the Koyva Horizon, but most recently it has been assigned to the Biya suite (Tsyganko et al. 1987, Tsyganko 2011). In section 126 on Shchugor River in the same area as the type locality, unfigured specimens of "Pseudozonophyllum versiforme" occur $58 \mathrm{~m}$ below conodonts Polygnathus patulus and $68 \mathrm{~m}$ below P. costatus (Tsyganko et al. 1987; Tsyganko 2011, fig. 51). Since the Biya beds overlie strata assigned to the Vyazovaya beds, (inversus to serotinus conodont Zone according to Khalymbadzha \& Chernysheva 1990), the type stratum of ?Digonophyllum versiforme is likely to be late Emsian, serotinus or patulus Zone.

Additional material. - Apparent topotypes in the Geological Survey of Canada's collections are labelled in latin and cyrillic: "Pseudozonophyllum versiformis (Markov) (Actinocystis versiformis) Sr. Ural, Kuye-Alexander. Zavod. $\mathrm{D}_{2}{ }^{1}$ ". The present author first saw these specimens in a reference collection maintained by D.J. McLaren and A.W. Norris, but does not know how they became part of that collection which has since been disbanded. Eight of these apparent topotypes, now numbered GSC 140114140121, are evidently the same species as those illustrated in Markov's (1923) plate 6, figures 2-5 and possibly are the same as those of his text-figure 1 and figures $6-12$ of his plate.

McLean (1976) thought that most of Markov's specimens, including the unsectioned specimen illustrated in figure 1 of Markov's plate are probably (p. 17) or questionably (p. 16) conspecific with Digonophyllum rectum (Meek, 1868). Here it is thought that compared to D. rectum, Markov's specimens of Digonophyllum are cylindrical rather than ceratoid and have longer major septa forming a more distinct keyhole fossula.

Description. - The apparent topotypes of Actinocystis versiformis Markov, 1923 in the GSC collections are considered here to belong to a single species of Digonophyllum described as follows. Solitary rugose coral, some specimens of which may have had a discoid or up side down saucer-shaped corallum in early stages (juvenile coralla not represented in the GSC apparent topotypes). Maximum diameter of the theoretically discoid forms, measured from longitudinal sections, is about $25 \mathrm{~mm}$. Subsequent development of the corallum typically increased its diameter very little, so that adult coralla are typically more or less cylindrical with only very minor rejuvenations (Fig. 2F). Maximum observed height of corallum $>50 \mathrm{~mm}$. Calice moderately deep and lacking a platform in late stages.

In the earliest stages for which a transverse section (diameter $11.2 \mathrm{~mm}$ ) is available in the GSC material (Fig. 2B) septa are sufficiently dilated periaxially to be all but totally in contact. Peripherally, septa are also strongly dilated mostly leaving only very narrow gaps between them. Although a few very short minor septa can be seen, protosepta are not clearly distinguishable from metasepta. A section at a slightly higher level (diameter $12.4 \mathrm{~mm}$ ) shows (Fig. 2C) similar septa, although gaps between them are wider in the peripheral region. At approximately $16.0 \mathrm{~mm}$ diameter, a damaged transverse section through the same specimen shows (Fig. 2E) what appears to be a very early stage of a keyhole fossula. Numerous small dissepiments are visible between septa which peripherally at this stage are about as wide as the gaps between them. A transverse section through a more advanced stage in another specimen (Fig. 2J) is extraordinary, not just because of its inexplicable distortion, but because it shows attempts to develop keyhole fossulae at two different locations. As oriented in Fig. 2J, the shortened cardinal septum of the earlier keyhole fossula is positioned at the lowest point of the figure. In the same figure, the "cardinal" end of the final keyhole fossula is positioned about $48^{\circ}$ to the left of vertical. The longitudinal section shown in Fig. 2F is of the earliest and intermediate stages of the same specimen shown in Fig. 2J. A transverse section through the mature stage of the same specimen is shown in Fig. 2A. A similar section of another specimen is depicted in Fig. 2D. In these mature stages there are 58-60 major septa, two of which can be tentatively identified as cardinal and counter septa. However, in light of Fig. $2 \mathrm{~J}$, they are presumably not continuous with previous apparent cardinal and counter septa. Septal arrangement in mature stages produces a single well-formed keyhole fossula (clear in Markov's, 1923, pl. 6, fig. 4 as well as Fig. 2A, D herein). Major septa are long although most are variably disrupted in the peripheral region. Around the keyhole fossula neighboring septa are in contact. Minor septa are confined to the peripheral region, and much disrupted. Some are little more than minor projections from the inner corallum wall. Major and minor septa are constructed entirely of monacanthine trabeculae, and lack both alternate and crossbar carinae. Greatest diameter of trabeculae in the earliest, presumably discoid stage of development $0.5 \mathrm{~mm}$. Diameter of trabeculae in late cylindrical stage with well developed keyhole fossula varies from about $0.13 \mathrm{~mm}$ where the septa are thinnest, to as much as $0.7 \mathrm{~mm}$ around the fossula.

In early stages, as the theoretical discoid corallum assumes upward growth to become cylindrical, dissepi- 
ments are few and may be flat lying or even slightly outwardly inclined. Higher, where the corallum has become cylindrical, dissepiments are more numerous. As seen in longitudinal section, they are small, well inflated and all but the outermost are inwardly inclined with inclination increasing adaxially. There are as many as 14 rows of dissepiments in late stages. Large dissepiments of the inner rows grade into inwardly inclined outer tabellae of the tabularium. In transverse section many of the outer dissepiments are seen to be incomplete and include some that are lateral. The tabularium is narrow and deeply depressed in the keyhole fossula.

Remarks. - Markov (1923) noted that a great number of specimens occur at the level of Calceola sandalina at the type locality and that his study was based on 60 specimens. He believed the species' extreme variation depended directly on the rate of sedimentation of the deposits surrounding an individual specimen. Essentially, four morphologies were recognised and illustrated on his plate 6 . These were: a) flat discoid with sharp edge as in figure 9; b) patellate like a saucer according to Markov as in figures $6,7 ; \mathrm{c})$ variably conical with differently directed curvatures as in figure 1; and d) correct cylindrical as in figure 2. It is reasonable to assume that Markov's use of the word "correct" for the cylindrical form indicates that the holotype is, or resembles the unsectioned cylindrical specimen shown in figure 2 of his plate. This is the same form as that of the also unsectioned specimen illustrated by Soshkina (1949, pl. 24, fig. 1). A similar cylindrical form in the Geological Survey of Canada's collections has been sectioned and is illustrated in Fig. 2A, F, and $\mathrm{J}$ of the present paper.

The species was originally referred to Actinocystis and later moved to Pseudozonophyllum. With some reservation, pending firm information on the holotype, the species is here referred to Digonophyllum. Actinocystis is an unrelated Silurian ptenophyllid genus with closely spaced tabulae and a well defined boundary between tabularium and dissepimentarium (Hill 1981, p. F246, fig. 155, 2c). Pseudozonophyllum halli Wedekind, 1924 (pp. 25, 28, figs 28-31) has been chosen (Lang et al. 1940, p. 110) lectotype of Pseudozonophyllum Wedekind, 1924 (p. 25). In adult stages it differs from species of Digonophyllum and other digonophyllids in having incomplete, and peripherally as well as adaxially dilated septa which cannot be considered septal crests and do not form a keyhole fossula. Hill (1981, p. F115, fig. 54, 2c-e) and Lin et al. (1995, p. 142, fig. 79a-c) all place $P$. halli in Zonophyllum Wedekind, 1924 (p. 12).

McLean (1976, pp. 16, 17) believed that the discoid specimen of Actinocystis versiformis illustrated in figure 9 of Markov's 1923 plate is probably a specimen of "Glossophyllum" discoideum Soshkina, 1936, and that Markov's other illustrated specimens of $A$. versiformis may be conspicific with Digonophyllum rectum (Meek, 1868). After study of apparent topotypes of $A$. versiformis in the Geological Survey of Canada's collections, the present author also believes that the type series of Markov's species includes at least two genera and species. The genera are Digonophyllum for Actinocysis versiformis and Devonodiscus gen. nov. for "Glossophyllum" discoideum. Assuming that the specimens shown in Fig. 2 of the present paper are correctly identified as conspecific with the problematic holotype of $A$. versiformis, Digonophyllum rectum is distinguished from $D$. versiforme by the very much smaller apical angle of its corallum and much less clearly defined keyhole fossula. Also, in Meek's species the average diameter $(c .30 \mathrm{~mm})$ of the adult corallum is the same as that of $D$. versiforme but the species has a maximum of $53 \times 2$ septa versus $60 \times 2$ in D. versiforme.

Although the majority of corals identified in the literature as Pseudozonophyllum versiforme are inadequately known, most are clearly not conspecific with Digonophyllum versiforme (Markov) of the present paper. The form from the Eifelian Mamentovo beds of the Salair lacks a keyhole fossula, is trochoid and better placed in Lekanophyllum Wedekind, 1924. Specimens from the Emsian Shandin beds of the same Salair region (Zheltonogova \& Ivaniya 1961, Ivaniya 1965, Elkin et al. 1985) have a week keyhole fossula and should be placed in Digonophyllum. However, they are larger with fewer septa, which are withdrawn from extensive regions of the dissepimentarium. Corals from the Emsian Losishin beds of Rudny Altay identified as P. versiforme by Spasskiy $(1960 b, 1977)$ and listed under the same name by Kozlov \& Dubatolov (1994) are here regarded as small (diameter 20-22 mm) specimens of Lekanophyllum having a maximum of $36 \times 2$ radially arranged septa. Kravtsov (1963) monographed a single specimen from the Pragian Yukhoda beds of the south Taimyr fold belt as a specimen of $P$. versiforme. Here, this specimen is thought more likely to be a specimen of Digonophyllum elegans (Kravtsov, 1963) which also occurs in the Yukhoda beds, and which in late stages has an open keyhole fossula, mostly formed of tabellae not dilated septal ends (see Kravtsov 1963, pl. 12, fig. 2v). Ulitina (1968) referred eight incomplete corals from the Eifelian of the Transaucasus to $P$. versiforme. They have septal cones with moderately long major septa separated by many small incomplete dissepiments and fragmented minor septa. Although the septal cones may be slightly excentric, there is no indication of any kind of septal fossula. These corals, which are believed (Spasskiy 1983) to have originated in the Volcheverota Suite on the Armenian part of the Iranian plate, are better placed in Lekanophyllum. Two works (Bul'vanker 1965, Besprozvannykh et al. 1975) report $P$. versiforme from the Prekolyma terrane of northeastern Russia. Bul'vanker's one or two specimens are small or juvenile specimens 

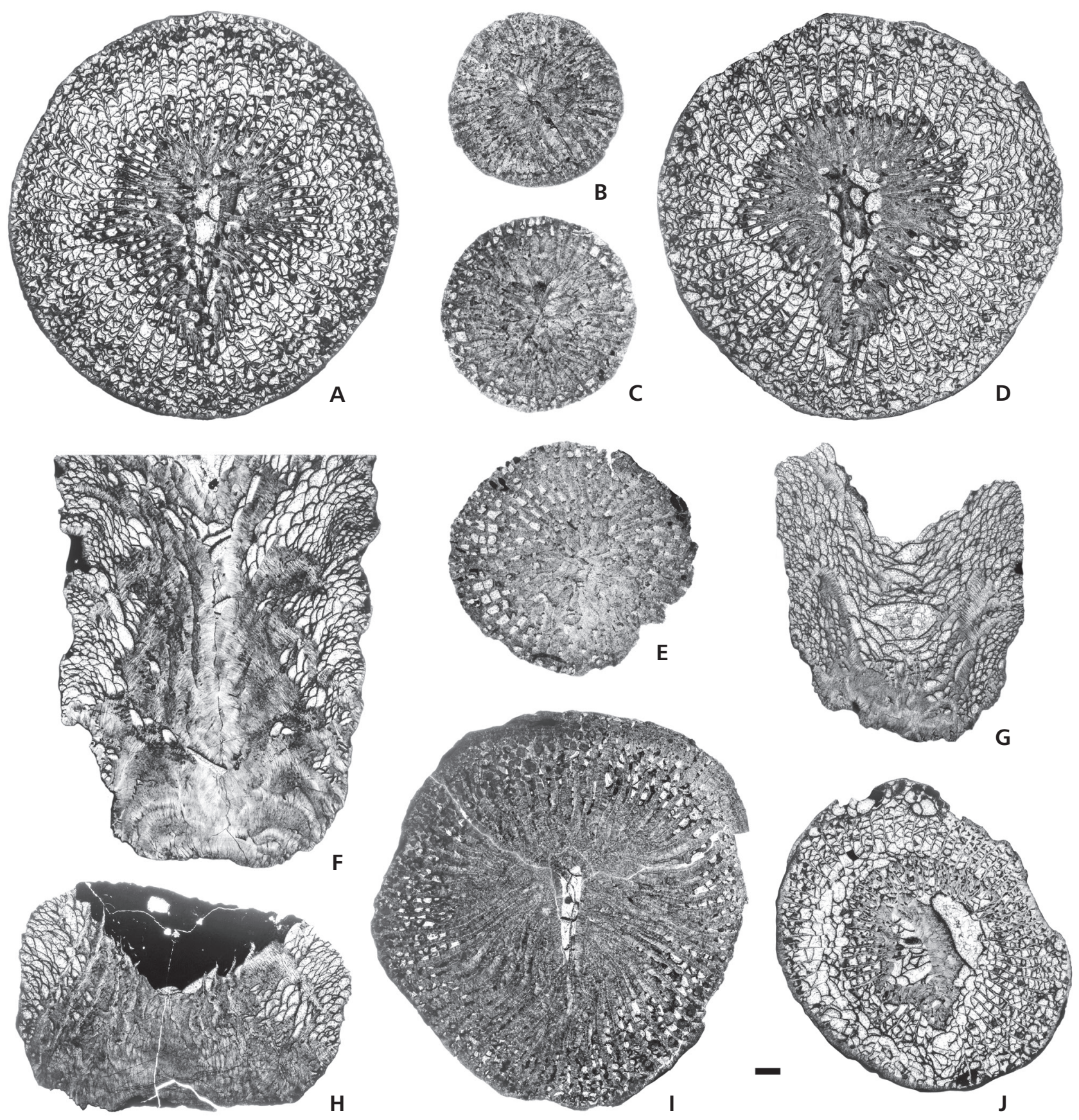

Figure 2. Digonophyllum versiforme (Markov). Probable topotypes, labelled Koyva beds, near Kus'e Alexandrov Works, central Western Urals, Russia; A, F, J - GSC 140114, two transverse and a longitudinal section; B, C, E - GSC 140117, successive transverse sections (B lowest, E highest) through lower corallum; D - GSC 140115, transverse section through a mature stage; G - GSC 140116, longitudinal section through a medium size specimen; H - GSC 140118, longitudinal section through early stages of a normal size specimen; I - GSC 140119, damaged transverse section through a late but not fully mature stage. Scale bar represents $2 \mathrm{~mm}$.

with a narrow trochoid to almost ceratoid corallum. The single specimen monographed by Besprozvannykh et al. (1975) is part of the adult stage. It has a narrow dissepimentarium and a wide tabularium comprised of numerous tabellae, and its septal arrangement is radial without a fossula. Artyushkova et al. (2011, p. 15) who may have been quoting A.G. Baikuchkarov's identification (p. 6) listed Digonophyllum versiforme (Mark) from the Koyva Horizon of the Inzer and Sikaza river outcrops of the southern West Uralian Fold Zone. 
Occurrence. - What appear to be certain occurrences of the species are confined to the Biya suite and Koyva Horizon (Russian gorizont) of the western slopes of the northern and central Urals, and to subsurface Sandak beds of the southeastern Volga region of the Russian Platform. Ages of these occurrences are probably early Eifelian, partitus to costatus conodont zones. Age of the undescribed specimens from the western slopes of the Southern Urals is said to be (Artyushkova et al. 2011, pp. 13, 15) late Emsian serotinus conodont Zone to early Eifelian costatus conodont Zone.

Family Hadrophyllidae Nicholson, 1889

Diagnosis. - Weyer (1975, pp. 14, 15, tab. 1) briefly diagnosed the Hadrophyllidae as having a discoid or turbinate corallum (questionably with an everted calice), an archaeotheca, lamellar septal microstructure, shortened cardinal septum and short minor septa. Two genera were included, Hadrophyllum Milne Edwards \& Haime, 1850 for species with a turbinate corallum, and Microcyclus Meek \& Worthen, 1868 for those with discoid coralla.

Plusquellec (2006) revised Hadrophyllum orbignyi Milne Edwards \& Haime, 1850, the type species of the genus, in preparation for erecting $H$. asturicum Plusquellec, 2005. As currently known, the genus includes these two similar species only. The longer of Plusquellec's 2005 and 2006 diagnoses may be translated as follows.

Polyp solitary and small, globular or more or less flattened cushion-shaped and generally asymmetric (bilaterally symmetrical). Central area of calice convex, rarely concave or concavo-convex, proximal surface invariably lacks an "epitheca". Line of contact between the proximal and distal zones always gradual and rounded. Proximal apex is a conical stalk, circular in plan view and slightly excentric towards the counter side. Cardinal and alar fossulae well developed, rhopaloid and closed. Counter fossula distinct, commonly asymmetrical and morphologically variable. Cardinal protoseptum thin, long or short, complete or incomplete, may not be visible, and is either straight or bent to the right or left. Counter, counter-lateral and alar septa morphologically similar to major metasepta. Major metasepta contratingent with frequent irregularities leading to differently shaped spaces between them. Minor metasepta contratingent, confined to the calicular border. Interspeptal crests abundant. Major and minor septa extend over the proximal face in the form of ridges, commonly shortened around the apical zone. Contiguous costosepta with non-trabeculate fibrous mincrostructure form a septothecal wall. Tabulae and dissepiments absent. The polyp almost or totally surrounds the corallum allowing automobility.

Remarks. - Nicholson in Nicholson \& Lydekker (1889, p. 296) wrote that "certain singular little discoid" Devonian Zaphrentoid corals "may be provisionally spoken of as the Hadrophyllidae". The provisional taxon comprised the genera Hadrophyllum, Baryphyllum, Combophyllum and Microcyclus. A new illustration (fig. 176) of Microcyclus discus was provided. Nicholson noted that these genera have conspicuously bilateral septal symmetry, their septa are irregular in length and smoothedged, and that their interseptal loculi are filled with stereoplasma. He also noted the absence of tabulae and dissepiments. The four genera have been discussed by many authors, especially by Stauffer (1952), Fraunfelter \& Engstrom (1970), Birenheide (1971) and Plusquellec (1972) for Microcyclus, Weyer (1973) for Baryphyllum, Plusquellec \& Semenoff-Tian-Chansky (1973) and Weyer (1975) for Combophyllum, and by Plusquellec (2006) for Hadrophyllum. The family as a whole has been discussed and revised in the works of Weyer (1973, p. 56; 1975, pp. 15-17) and Plusquellec (2006).

Most authors, including those of the Kansas (Hill 1981) and Beijing treatises (Lin et al. 1995), have given the authorship of the Hadrophyllidae to Nicholson (1889). Stumm (1949, p. 5) considered the Nicholson authorship to be invalid because it was provisional, and used the Hadrophyllidae as a new family. However, Nicholson's authorship of the Hadrophyllidae is upheld by articles 11.1 and 12.1 (date between 1757 and 1931), and 11.7 (description required) of the ICZN Code (1999).

Two, possibly three subfamilies within the Hadrophyllidae were proposed by Plusquellec (2006). The subfamilies Microcyclinae and Hadrophyllinae were firmly included, while Cummingsiinae Weyer, 1975 was added with reserve. Because of their discoid and non-archaeothecate coralla and fibrous septal microstructure, the Microcyclinae are raised to family rank in the present paper.

Figure 3. Devonodiscus latisubex gen. et sp. nov. Holotype and topotypic paratypes from upper Hume Formation, Mountain River, Mackenzie Mountains, GSC Loc. C-049670. Where possible, illustrations oriented to place cardinal septum at lower part of transverse sections and distal views; A, E - holotype, GSC 140122, exterior side and proximal views before preparation; B, J - holotype, parts of transverse sections through final calice (B) and near base of corallum (J); C, D - GSC 140128, 140127, exterior distal views; F - holotype, longitudinal section; G, H, I - GSC 140129, 140134, 140130, exterior distal views; K, M - GSC 140124, transverse sections; L - GSC 140131, transverse section near base of small specimen; N - GSC 140123, transverse section; O - GSC 140125, longitudinal section approximately perpendicular to cardinal-counter plane; P - GSC 140126, longitudinal section approximately in cardinal (right side)-counter plane; Q - GSC 140133, transverse section near base of calice. Scale bars represent $2 \mathrm{~mm}$. 


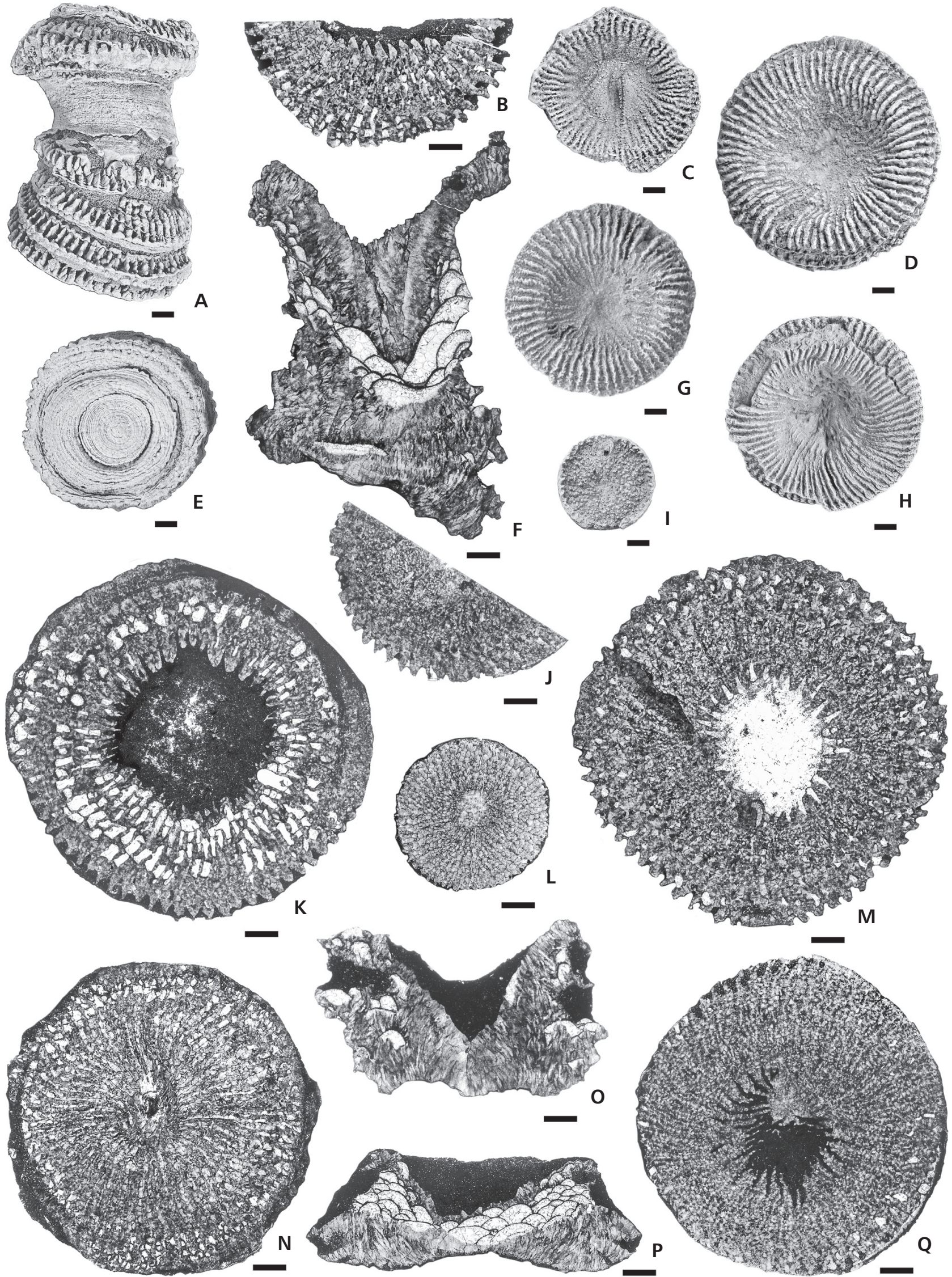


Family Microcyclidae Plusquellec, 2006 nov. status

Type genus. - Microcyclus Meek \& Worthen, 1868.

Diagnosis. - Family of solitary Rugosa with discoid corallum. Proximal face of corallum mostly more or less flat, epithecate with closely spaced concentric or almost concentric growth increments. Distal surface mostly weekly convex with a very slightly depressed periaxial area. Cardinal, counter and alar septa, an open cardinal fossula and interseptal spaces present on distal surface of corallum. Minor septa either free, or more commonly contratingent with the cardinal side of major septa. Septal surfaces smooth (Stauffer 1952, pls 1-7; Plusquellec 1972, fig. 6, pls 6, 7). Septal microstructure recrystalized in all available thin-sectioned material, but certainly non-trabeculate (Birenheide 1971, figs 2a-3) and fibrous ("fibrocristaux", Plusquellec 1972). Dissepiments and tabulae absent.

Remarks. - Proposed (Plusquellec 2006, p. 222) as a subfamily of the Hadrophyllidae. The principal feature distinguishing the Microcyclidae from the, Hadrophyllidae, is that the Hadrophyllidae are archaeothecate (well illustrated in Plusquellec 2006, fig. 10) with soft parts that would have enclosed the entire hard skeleton (Weyer 1975, p. 7). This is also the principal reason for promotion of the Microcyclinae to family status.

Genus composition. - In addition to the type, Crassicyclus Soto, 1979 (p. 426, pl. 1, figs 1-13) which was included in Plusquellec's Microcyclinae is retained in the Microcyclidae.

Family Devonodiscidae fam. nov.

Type genus. - Devonodiscus gen. nov.

Diagnosis. - Family of solitary Rugosa corals. Corallum epithecate with fine growth increments on all outer surfaces. In early stages corallum discoid with shallow calice. In adult stages corallum may rejuvinate more than once but remain essentially discoid (lower part Fig. 3F, whole 7E), or become cylindrical with deep calice (Fig. $5 \mathrm{~A}, \mathrm{~J})$. In gerontic stage corallum may become pulleyshaped (trochlear) as illustrated by Tsyganko (1980, fig. 2a, c, d) and herein (Figs 3A, 4A). Where corallum is discoid or pulley-shaped, septa are prominent as closely spaced ridges over the calice. Minor septa may or may not be contratingent. Septa trabeculate (Tsyganko 1980, fig. $2 \mathrm{~g}$ ) and herein (Figs 3O, 4G). Trabeculae holacanthine, originally probably monacanthine. Septa reduced, or in extreme cases are entirely absent (Figs 5B, 6E) in cylindrical parts of coralla. Horizontal skeletal elements are mostly recognizable as dissepiments except in cylindrical parts of coralla where they become variably inclined undulating plates (Fig. 5O).

\section{Genus Devonodiscus gen. nov.}

1868 Combophyllum Edwards \& Haime, 1858 [sic!]. Meek, p. 84. (Apparent error for Milne Edwards \& Haime 1850)

? 1868 Palaeocyclus. - Meek, p. 85. (non Milne Edwards \& Haime 1850)

1936 Glossophyllum. - Soshkina, p. 64. (non Wedekind 1923)

partim 1937 Microcyclus? - Bassler, p. 195. (non Meek \& Worthen 1868)

? 1954 Hadrophyllum. - Packham, p. 121. (non Milne Edwards \& Haime 1850)

1956 Palaeocyclus? - Warren \& Stelck, explanation pl. 1, fig. 4. (non Milne Edwards \& Haime 1849)

1960a Palaeocyclus. - Crickmay, p. 1.

partim 1962 Chonophyllum. - Soshkina et al., pp. 291, 293. (non Milne Edwards \& Haime 1850)

1971 "Microcyclus". - Pedder, p. 51.

1978 Devonodiscus. - Uyeno, p. 252. [inadvertent use of nomen nudum ]

2017 “Microcyclus". - Pedder, p. 352.

Type species. - Devonodiscus latisubex sp. nov. Pedder (2017, p. 353) indicated that the type for an anticipated new genus, i.e. for the then nomen nudum Devonodiscus, would be Combophyllum multiradiatum Meek, 1868. However, since the only original specimen of Meek's species is water-worn and comes from an unknown stratum and location, D. latisubex is preferable as type for the new genus.

Etymology. - Devon from the Devonian System, and Latin noun discus a circular plate, with o as a connective. Gender masculine.

Figure 4. Devonodiscus latisubex gen. et sp. nov. Paratypes from upper Hume Formation, Powell Creek, GSC Loc. C-003871, except where otherwise stated. In complete transverse sections the cardinal septum is placed at the lowest point of the illustration; A - GSC 140151, longitudinal section; B, D - GSC 140139, longitudinal section and part transverse section through calice; C - GSC 140144, transverse section through base of calice; E, H, M, N - GSC 140156, GSC Loc. C-024674, type section of Hume Formation, two part transverse sections through "stalk" stage (E, H), complete longitudinal (M) and part transverse section through first calice (N); F, J - GSC 140152, GSC Loc. C-012175, tributary of Powell Creek, transverse sections from same specimen; G - GSC 140145, longitudinal section; I - GSC 140136, longitudinal section; K - GSC 140146, longitudinal section of immature specimen; L- GSC 140141, longitudinal section. Scale bar represents $2 \mathrm{~mm}$. 

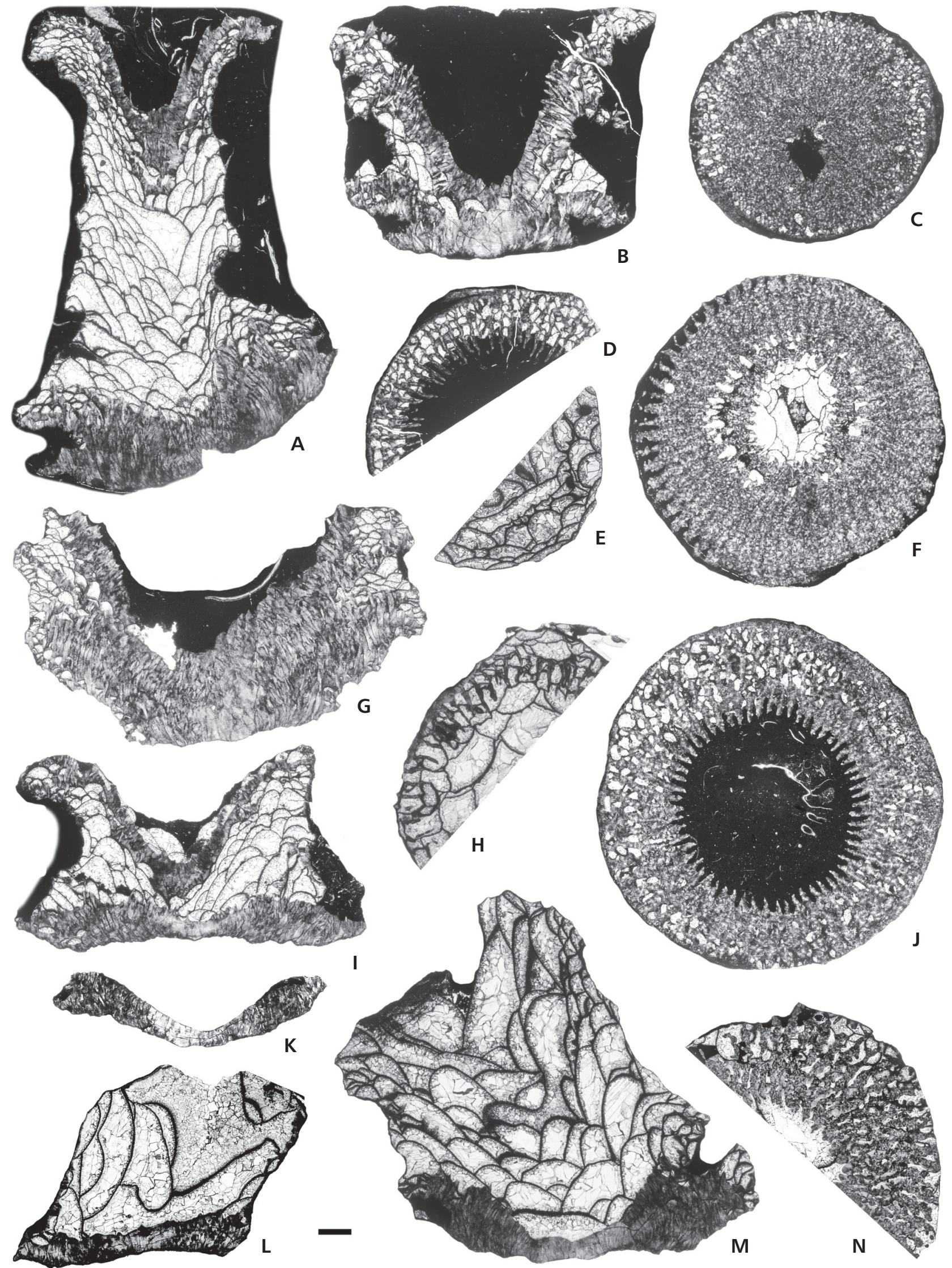
Diagnosis. - Since Devonodiscus is the only genus in the family its diagnosis is the same as that of the Devonodiscidae.

Description. - Corallum solitary, discoid or almost discoid in earliest stages. In later stages corallum either remains discoid with (Fig. 7E) or without (Fig. 7K) rejuvenations, or becomes partly cylindrical (Fig. 3A, F). In discoid coralla epitheca is confined to lower surface (Fig. 3E); in partly cylindrical coralla epitheca surrounds both the lower surface and the cylindrical part (Fig. 5J). Concentric growth increments visible on proximal surface of all coralla (Figs 3E, 7G). Calice in discoid coralla has an almost uniformly broad excert peripheral region (Fig. 8D). Calices above strongly rejuvenated or partly cylindrical coralla are moderately (Figs 4G, 6B) to deeply (Fig. 5A) conical. Cardinal fossula only clearly evident in periaxial area where it is thin and in some specimens slightly rhopaloid (Fig. 7N) and bent (Fig. 7A). No alar fossula present.

Bilateral septal arrangement evident in transverse views of most specimens, but is difficult to discern in very early stages (interior of Fig. 8B, entire Fig. 3I) and transverse sections through excert part of upper calice (Fig. 4J). Counter lateral protosepta just longer than the counter protoseptum, all three extend close to the cardinal fossula. Cardinal protoseptum long, straight (Fig. 7L) or periaxially curved (Fig. 7A). Alar protsepta may (Fig. 7A) or may not (Fig. 7B) be clearly distinguishable in calicular views. Alar protosepta and major metasepta long but do not extend to the axis. Trabeculae forming the septa are rarely perfectly aligned, the resultant costation varies from weak (Fig. 7L, N) to strong (Fig. 3G). Fine structure of holacanths before crystalizaton not evident in any prepared Canadian material.

Horizontal skeletal elements absent from some species, abundant in adult stages of other species. Horizontal elements may comprise inwardly to outwardly sloping dissepiments as well as large inwardly sloping tabellae.

Remarks. - Devonodiscus was first mistaken for Combophyllum. It is easily distinguished from Combophyllum by its epithecate condition, which contrasts fundamentally with the archaeothecate or euthecate condition of Combophyllum. Plusquellec \& Semenoff-Tian-Chansky (1973) published excellent photographs of Combophyllum, including lower views of C. osismorum (their pl. 1, fig. $1 \mathrm{~b}, \mathrm{pl} .2$, fig. 1b) which differ strikingly from views of the lower surface of Devonodiscus multiradiatus (Fig. 7G, J, herein).

The synonymy of Devonodiscus includes a questioned use (Meek 1868) of Palaeocyclus for a possible Alaskan occurrence of Devonodiscus and two unquestioned occurrences of the genus in the Northwest Territories (Crickmay 1960b, Caldwell 1971). Palaeocyclus Milne Edwards \& Haime $(1849$, p. 71$)$ is not firmly established by a type specimen or series for its type species (Hill 1981, p. F96). Good photographic illustrations of an approximate topotype of the type species (Bassler 1937, pl. 30, figs 1-4) are available. These show an epithecate discoid corallum and septa which are obviously trabeculate (monacanthine according to Hill, op. cit.). However, the septa are not contratingent and not separated to form fossulae, and confirm Hill's (op. cit.) statement that the genus lacks both dissepiments and tabulae.

From Soshkina (1936) to Tsyganko (2011) Russian authors with only one exception have referred Russian species here included in Devonodiscus to Glossophyllum Wedekind, 1924 (p. 76), which by subsequent designation of Lang et al. (1940, p. 63) has G. dohmi Wedekind (1924, p. 77) for type species. Birenheide (1969, p. 40 footnote) chose the transverse section illustrated in Wedekind's (1924) fig. 112 as lectotype of G. dohmi. Unfortunately no longitudinal thin section or remnant has been preserved of the lectotype. However, it is generally thought (Hill, 1981, p. F298) to be close to and congeneric with Cyathophyllum ceratites Goldfuss, 1826 (p. 57), which is adequately known principally from works by Birenheide (1969, p. 39, pl. 3, fig. 9, pl. 5, fig. 16) and Lütte (1987, p. 441, pl. 4, figs 16,17 , pl. 5 , figs $18-22$, pl. 6 , figs 24,25 , pl. 7 , fig. 28). Study of the present author's material from the upper Eifelian of the Hillesheimer Mulde, of Lütte's (1987) and Schröder's material (1998, p.32, pl. 3, figs 12-19, pl. 4, figs 20-26) from the upper Eifelian and lower Givetian of other parts of the Eifel, and of Schröder \& Kazmierczak's (1999, p. 99, pl. 2, fig. 6) material from Morocco leads to a definition of Glossophyllum which is significantly different from that of Devonodiscus. Glossophyllum has a ceratoid to trochoid or cylindrical corallum which is not known to be discoid or patellate at any level, and has long thin, minor as well as major septa, and broad interseptal spaces. Very fine inwardly projecting trabeculae appear

Figure 5. Devonodiscus latisubex gen. et sp. nov. Paratypes from upper Hume Formation, Powell Creek, Mackenzie Mountains, except where otherwise noted, GSC Loc. C-003871 or C-003872; A - GSC 140149, longitudinal section; B, F, I, J, K, P - GSC 140148, exterior side view of corallum before preparation $(\mathrm{J})$ and transverse sections from successively higher levels in the same corallum (P lowest, B highest); C, D, G - GSC 140154, exterior basal and side views before preparation, and longitudinal section of same specimen; E, H, R, S - GSC 140137, successive transverse sections (S lowest, E highest) and longitudinal section (R) from near base of same corallum; L - GSC 140147, longitudinal section; M - GSC 140163, GSC Loc. C-083491 longitudinal section of a specimen from Imperial Hills; N, O, Q - GSC 140153, GSC Loc. C-024674, exterior side and basal views before preparation and longitudinal section of same specimen from type section of the Hume Formation. Scale bars represent $2 \mathrm{~mm}$. 

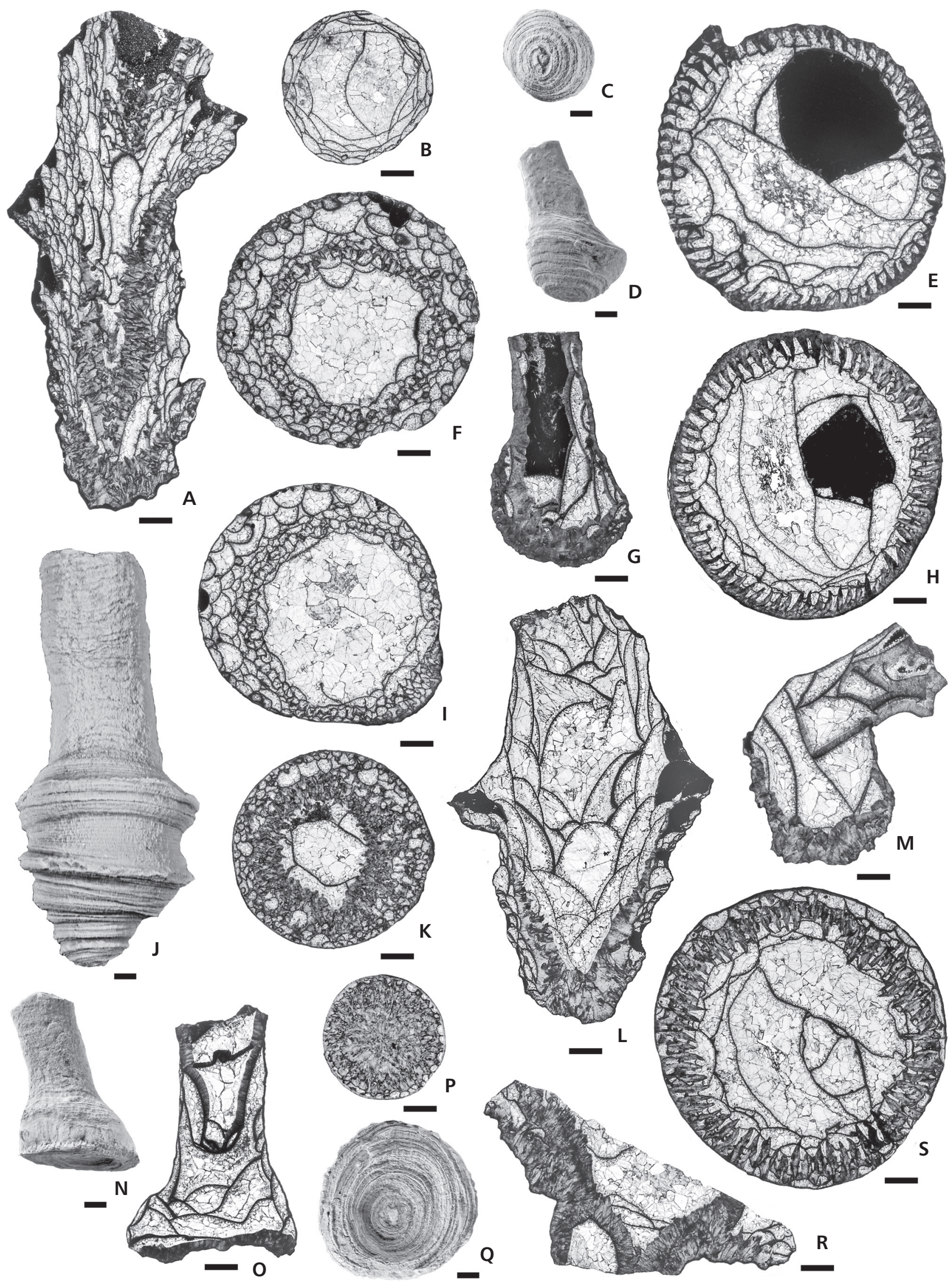
to be present only in the outermost part of some septa. In adult stage, Glossophyllum has in inwardly sloping dissepimentarium comprised of numerous small dissepiments, and a broad tabularium with flat to concave tabulae and tabellae.

The exception to assignments to Glossophyllum is Soshkina et al. (1962) assignment of Devonodiscus discoideum to Chonophyllum Milne Edwards \& Haime (1850, p. 1xix), which has the Silurian coral C. perfoliatum Goldfuss in Milne Edwards \& Haime (1850), as type species. From investigation by Smith $(1945$, pp. 19, 20) and diagnosis by Hill (1981, pp. F216, F217) Chonophyllum differs from Devonodiscus, at least, by being turbinate, having numerous rejuvenated, naotic dissepimentaria and a very narrow tabularium.

The best known Canadian species of Devonodiscus has been taxonomically associated with the genus Microcyclus Meek \& Worthen, 1868 for decades. However, Devonodiscus is distinguished from Microcyclus by its generally longer and more closely spaced septa and especially by its traeculate microstructure, which make septal surfaces of well preserved specimens rough, not smooth as those of Microcyclus are. Furthermore, two of the three species definitely assigned to Devonodiscus apparently responded to adverse environmental changes by developing cylindrical to trochlear coralla with abundant horizontal elements, which are also unknown in Microcyclus.

Species composition. - In addition to the type, Combophyllum multiradiatum Meek, 1868 (redescribed below) and Glossophyllum discoideum Soshkina, 1936 (pp. 67, 75, figs 80,81 ) are assigned to the new genus. Glossophyllum primitivum Soshkina, 1949 (p. 82, pl. 6, figs 1a-3b) and Glossophyllum altissimum Soshkina, 1951 (p. 45, fig. 19, pl. 6, fig. 1a-e) are excluded from it. Best illustrations of the types of Soshkina's species are on her (1952), plate 22. Thin sections of the holotype of Glossophyllum primitivum (Soshkina 1951, pl. 6, fig. 2a, b; 1952, middle and lowermost parts of fig. 84) are apparently of a species of Digonophyllum. Illustrations of the holotype (Soshkina 1951, pl. 6, fig. 1a-d; 1952, pl. 22, all but left side part of fig. 80) and only other illustrated specimen (Soshkina 1951, pl. 6, fig. 1e; 1952, pl. 22, left side of fig. 80) of Glossophyllum altissimum show it to be a ceratoid coral with very deep calice and no horizontal skeletal element, which indicate that it is not Glossophyllum, Digonophyllum or Devonodiscus. Questionably three other named species are assigned to Devonodiscus. These are Palaeocyclus kirbyi Meek (1868, p. 85, pl. 11, fig. 5-5b) from the "Devonian Hamilton group" of "Porcupine River, Russian America, lat. 66 deg. 27 min. N, long. 143 deg. W", Hadrophyllum wellingtonense Packham, 1954 (see below) and Glossophyllum clebroseptatum Kravtsov, 1975 in Besprozvannykh et al. (1975) (also see below).
Two named but inadequately described species should possibly be added to Devonodiscus, depending mostly on their unknown microstructure. These are Combophyllum brancai Frech (1911, p. 21, pl. 10, fig. 4a-c) and Hadrophyllum intercalare Yin (1938, p. 40, pl. 1, figs 3-5, 9). Superior illustrations of these species have been published by Mansuy (1916, pl. 1, fig. 1) and Fontaine (1961, pl. 1, fig. 1, pl. 3, fig. 3, pl. 18, fig. 4) for C. brancai, and by Yu et al. (1974, pl. 104, figs 4-7) for $H$. intercalare. Both species occur in Rostrospirifer tonkinensis-bearing units of the Huanan block of Northern Vietnam and Southern Yunnan, China.

Occurrence. - Middle and upper Eifelian in Northwest Territories, Canada. Eifelian of the western slope of the Northern and Central Urals, Russia. Upper Emsian or lower Eifelian (serotinus Zone) in the Tobasia section of Colombia (Y. Plusquellec personal communication 2016). Four questionable occurrences are: probable upper Pragian of the Molong-Monaro Terrane, southeastern Australia, Emsian of Northern Vietnam and Southern Yunnan, and most likely Middle Devonian ("Hamilton group") of the Alaskan part of the North American Plate.

\section{Devonodiscus latisubex sp. nov.}

Figures $3 \mathrm{~A}-6 \mathrm{~K}$

$$
\begin{aligned}
& 1972 \text { n. cystiphyllid gen. \& sp. - Lenz \& Pedder, } \\
& \text { p. } 34 \text {. } \\
& 1982 \text { "Microcyclus" multiradiatus (Meek). - Pedder, p. } 580 \\
& \text { (non Meek). }
\end{aligned}
$$

Type series. - Forty-four specimens, all from upper to uppermost Eifelian, Northwest Territories, Canada. Holotype, GSC 140122 and twelve topotypic paratypes, GSC 140123-140134 from GSC Loc. C-049670. Fifteen paratypes, GSC 140135-140149 from GSC Loc. C-003871 (loose specimens) and C-003872 (in-place specimens). One paratype, GSC 140150 from GSC Loc. C-012174. Two paratypes, GSC 140151, 140152 from GSC Loc. C-012175. Five paratypes, GSC 140153-140157 from GSC Loc. C-024674. One paratype, GSC 140158 from GSC Loc. C-025839. Three paratypes, GSC 140159-140161 from GSC C-025840. One paratype, GSC 140162 from GSC Loc. C-049662. Two paratypes, GSC 140163, 140164 from GSC Loc. C-083491. One paratype, GSC 140188 from GSC Loc. C-049669.

Etymology. - Latin adjective latus meaning broad, and noun subex meaning basal or under plate.

Diagnosis. - Species differentiated from other named species of Devonodiscus by its prominent septal carination (Fig. 4F, N), caused by irregular alignment of holacanths 

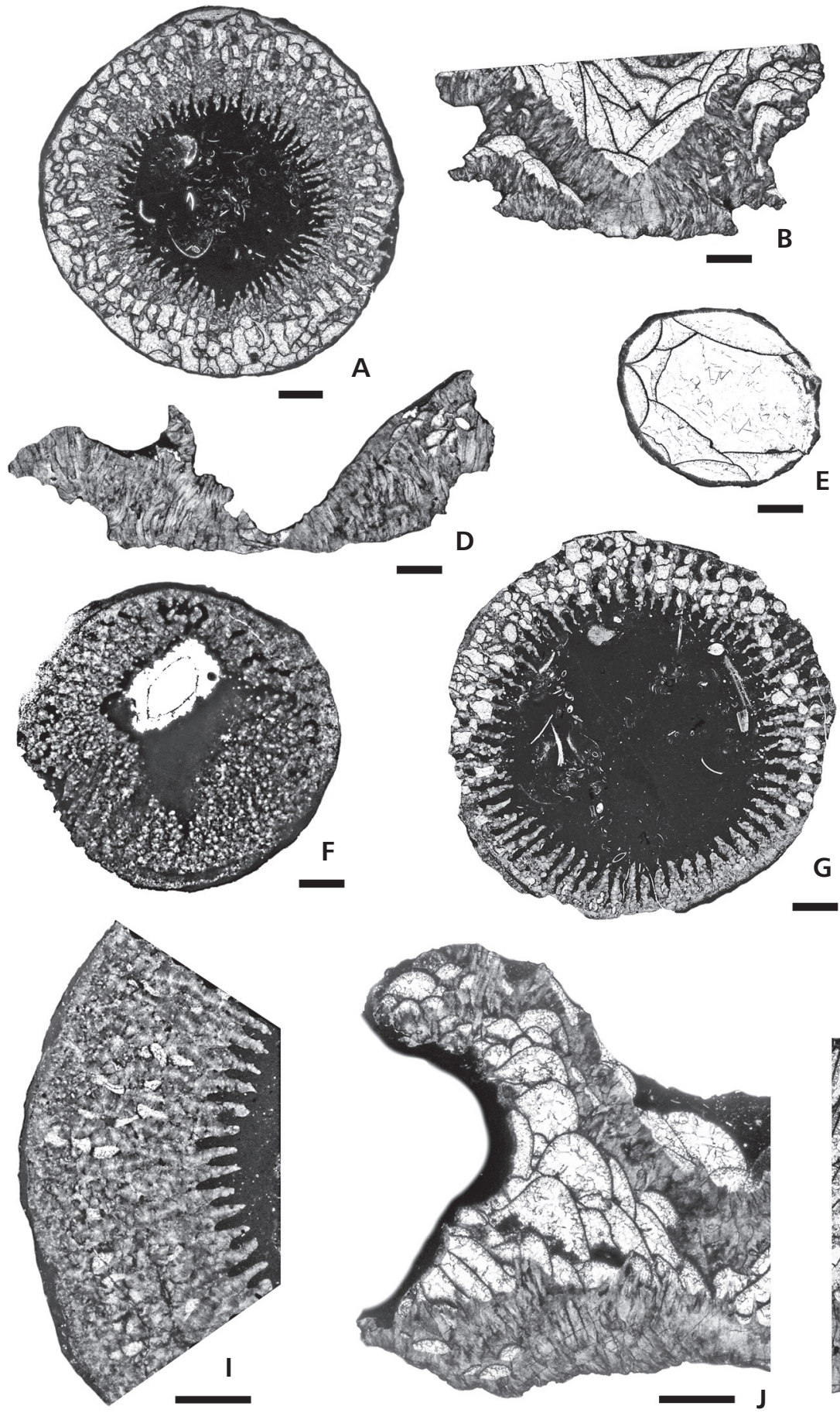
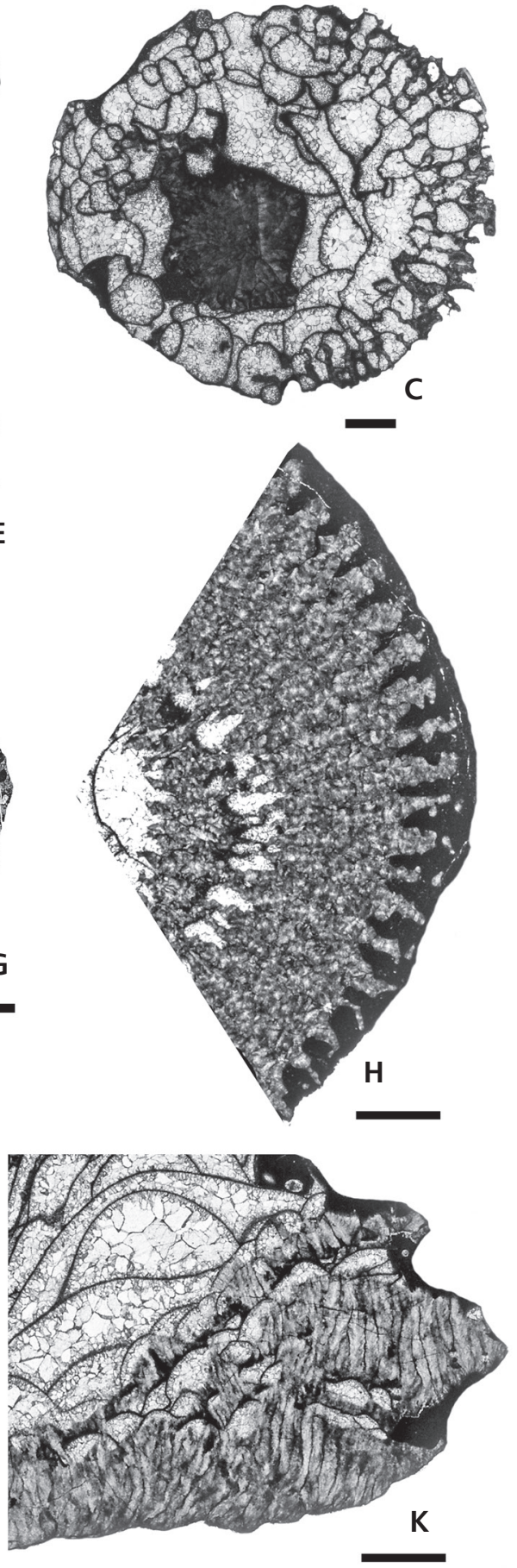

Figure 6. Devonodiscus latisubex gen. et sp. nov. Paratypes from upper Hume Formation, Powell Creek, Mackenzie Mountains, GSC Loc. C-003871, except where otherwise stated. Where possible, transverse sections oriented to place cardinal septum at lowest part of illustration; A, G-GSC 140140, transverse sections; B, C- GSC 140135, longitudinal and transverse sections; D - GSC 140142, longitudinal section; E - GSC 140143, transverse section through "stalk" (Tsyganko's 1980 term) part of corallum; F - GSC 140157, GSC Loc. C-024674, type Hume section, transverse section; H, I - GSC 140152, GSC Loc. C-012175, unnamed tributary of Powell Creek, parts of transverse sections; J - GSC 140136, part of longitudinal section; K - GSC 140162, GSC Loc. C-049662, unnamed tributary of Powell Creek, part of longitudinal section. Scale bars represent $2 \mathrm{~mm}$.

in its septal microstructure. It is also differentiated by the wide diameter of the cylindrical parts of its corallum (Figs $3 \mathrm{~A}, 4 \mathrm{M})$.
Description. - Corallum solitary. In early stage discoid with (Fig. 4B, G) or without (Fig. 4K) rejuvenescences. Following early rejuvenescences corallum may become 
slightly elliptical in plan view. Mature coralla are commonly partly cylindrical (Figs 3A, 5J). Epitheca with visible exterior growth increments, which may be slightly excentric, present on the proximal underside of all coralla (Fig. 5Q), also present on the outer surface of all cylindrical parts of coralla (Fig. 3A). Calice varies from almost flat (Fig. 4L) to just conical (Fig. 4K) in early stages. After several rejuvenescences (Fig. 4B, G) and above cylindrical parts (Fig. 4A), the calice becomes a deep upside-down cone. Most commonly, the outer calice-rim is variably excert. Calice inside cylindrical parts of a corallum is highly irregular and underlain by large dissepiment-like plates (Figs 4L, M; 5L).

Cardinal fossula, if defined as a calicular depression surrounding the cardinal septum, is present in most specimens. If however, it is defined as gaps between the cardinal septum and adjacent major metasepta in transverse sections below the calice, it is normally closed (Figs 3L, 4F) except at the outer periphery of the corallum (Fig. 3N). Cardinal fossula and septum more or less straight. Meta septa in cardinal quadrants may be curved so that their tips point more toward the counter septum (Fig. 3C, H). Other fossulae not evident as gaps in transverse sections below the upper calice.

Apparent random distribution of extremely short holacanths in early stages (corallum diameter $<8 \mathrm{~mm}$ ) makes the septa normally known as alar, counter and counter-lateral protosepta difficult to identify, in either exterior view (Fig. 3I) or transverse section (Fig. 5P). A paratype prepared as a transverse section is the smallest specimen (diameter $9.3 \mathrm{~mm}$ ) in which the protosepta are evident, although identity of only one of the alar septa is certain (left side Fig. 3L). Two minor and two major metasepta of the alar quadrant are contiguous and contratingent with it. The number of septa in an adult paratype (diameter $22.0 \mathrm{~mm}$ ) is 68 (Fig. $3 \mathrm{M}$ ). Because the major and contiguous minor septa are contratingent, the number of adaxial ends counted around the calice (diameter $8.0-9.0 \mathrm{~mm}$ ) is only 35 . In another adult paratype (diameter $21.0 \mathrm{~mm}$ ) prepared as a transverse section through the calice, holacanths are poorly aligned in a single row in one part of the section (upper left side Fig. 4J) but elsewhere are mostly aligned in more than one row (upper right side Fig. 4J). In the same section protosepta are not discernible and minor metasepta are not consistently differentiated from major metasepta. The total number of septa counted around the calice is 60 . In cylindrical parts of coralla, septa are reduced (Figs 4H, $5 \mathrm{~F}$ ) or entirely absent (Figs 5B, 6E).

Septal microstructure in the studied material has undergone diagenesis. In the least affected regions holacanths locally surrounded by structureless calite, presumed to be recrystallised lamellar tissue, are visible. Viewed in longitudinal section, the length of holacanths within septa is as much as $2.6 \mathrm{~mm}$ (Fig. $6 \mathrm{~K}$ ), and where they project above the distal edge of a septum, length of the resultant septal spine may be as much as $1.3 \mathrm{~mm}$ (Fig. 6B, J). In transverse sections holacanths commonly appear in one to three irregularly aligned rows within mostly thick septal lamellae (Fig. 6H). In discoid parts of the corallum, adjacent septa are contiguous for much of their length, regardless of whether they are proto- or metasepta of either order (Fig. 6H). Holacanthate septal spines and some carination appear on the adaxial ends of septa in all sections.

Some discoid coralla apparently lack dissepiments (Figs 4K, 5O). In specimens such as the holotype, which have undergone as many as three early rejuvenescenses, a few moderately well inflated dissepiments may be present near the periphery of the rejuvenated parts of the corallum (Figs 3B; 4G, M). In mature coralla with deep cone-shaped calices surrounded by septal cones, variable dissepiments in as many as six or seven rows underlie the septal cones (Figs 4I, 6J). In cylindrical parts of coralla where there is no septal cone, inward-sloping dissepiments meet at the possibly excentric basal apex of successive calices, so that no tabularium is formed (Fig. 4A).

Remarks. - Known in-place collections of Devonodiscus latisubex come from anoxic beds deposited immediately preceding the final stage of the Kačák Episode in the Mackenzie Mountains area, Northwest Territories, Canada. As formational boundaries are currently drawn, the species is confined to a thin sequence, $0.6-9.2 \mathrm{~m}$ below top of the Hume Formation. In biostratigraphic terms, D. latisubex is confined to the very late Eifelian, upper part of the Carinatrypa dysmorphostrota benthic assemblage Zone (Pedder 1975, 2017) and to the Polygnathus ensensis conodont Zone (Uyeno et al. 2017).

Two specimens from Powell Creek, identified as a new cystiphyllid genus and species by Pedder in Lenz \& Pedder (1972), have become illustrated paratypes of the species (Figs 5A, B, F, I-K, P).

Rare discoid specimens of Devonodiscus latisubex superficially resemble Combophyllum multiradiatum Meek, 1868, which was questionably re-assigned to Microcyclus Meek \& Worthen, 1868 by both Bassler (1937, p. 195) and Stumm 1951 (card 17). Before the new genus proposed herein was available, Pedder (1982) listed an almost discoid specimen from the upper Hume Formation at Powell Creek as "Microcyclus" multiradiatus (Meek). This specimen is now another illustrated (Fig. $4 \mathrm{~K})$ paratype of $D$. latisubex.

The closest species to Devonodiscus latisubex is Devonodiscus discoideum (Soshkina, 1936) from Eifelian beds of the Western Subarctic, Northern and Central Urals (Spasskiy 1955, p. 116; Tsyganko 1981, p. 123). The present author has not had the opportunity to study 
specimens of $D$. discoideum. Published information concerning designated types is confused. Soshkina (1936, pp. 16-20) discussed in detail occurrences of the species along the Malyi Patok River but did not list any type. Her illustrations were of black and white drawings of transverse (fig. 80) and longitudinal (fig. 81) thin sections. That they are of thin sections, and therefore not of the same specimen, is confirmed by explanations to figures la and $1 \mathrm{~b}$ on plate 7 of her 1949 publication. Thus they are syntypes, and not a holotype as has been claimed (Tsyganko 1981, p. 122). The 1949 illustrations, which are the first published photographs of the species, are reproduced with greater clarity in figure 81 on plate 22 of Soshkina's 1952 work. Another set of photographic illustrations of four apparently topotypic specimens of D. discoideum has been provided by Tsyganko (1980, fig. 2a-i). These are repeated with less clarity by Tsyganko, 1981 (pl. 53, figs 2a-5b), but include photographs (pl. 51, fig. 3, pl. 52, fig. 5) of two more apparent topotypes. In view of Soshkina's and Tsyganko's illustrations and careful descriptions (especially Tsyganko (1981) early discoid forms of $D$. discoideum and D. latisubex have essentially the same corallum diameters of $15-23 \mathrm{~mm}$, but the maximum number of septa in earlier discoid forms of D. latisubex is 72 compared to 68 in D. discoideum. Furthermore, arrangement of trabeculae is more scattered so the septa are more carinate in D. latisubex than in D. discoideum (compare Fig. $3 \mathrm{G}$ or $3 \mathrm{M}$ herein with Soshkina's 1952 , pl. 22, middle fig. 81 or Tsyganko's 1980, fig. 2e). The species are more easily distinguished by their responses to changes of depth in their surrounding sediments or to changes in their flat-lying position required for their vertical direction of growth. These responses normally involved a change to a narrower, cylindrical-shaped corallum. In D. latisubex the stem or cylindrical parts of the corallum are broader than those of $D$. discoideum, have more profuse tabellae and may have dissepiments (compare Tsyganko 1980, fig. 2a, v, z with Figs 4A; 5A, J herein).

Occurrence. - Upper Eifelian Carinatrypa dysmorphostrota benthic assemblage Zone and Tortodus kockelianus conodont Zone in the Hume Formation on the northwestern slope of the North American Craton.

\section{Devonodiscus multiradiatus (Meek, 1868)}

Figures 7A-9F

1868 Combophyllum multiradiatum n.; Meek, p. 84, pl. 11, fig. 4, 4a.

? 1868 Palaeocyclus kirbyi n.; Meek, p. 85, pl. 11, fig. 5-5b.

1905 Combophyllum multiradiatum Meek. - Schuchert et al., p. 157.

1923 Palaeocyclas kirbyi [sic!]. - Hume, pp. 55, 56.
? 1937 Paleocyclus kirbyi Meek. - Bassler, p. 190, pl. 30, figs 7-9.

1937 Microcyclus? multiradiatus (Meek). - Bassler, p. 195, p1. 31, figs 23, 24.

1950 Combophyllum cf. multiradiatum Meek. - Warren \& Stelck, p. 76.

1950 Palaeocyclus? cf. kirbyi Meek. - Warren \& Stelck, p. 76.

? 1951 Microcyclus? kirbyi (Meek). - Stumm, card 15.

1951 Microcyclus? multiradiatus (Meek). - Stumm, card 17.

1956 Palaeocyclus? kirbyi Meek. - Warren \& Stelck, pl. 1, fig. 4.

1956 Combophyllum cf. multiradiatum Meek. - Warren \& Stelck, pl. 1, fig. 5.

1960a Palaeocyclus kirbyi Meek. - Crickmay, p. 1.

1961 Microcyclus? kirbyi Meek. - Bassett, p. 488.

1962 Microcyclus? kirbyi (Meek) [sic!]. - McLaren, pp. 11, 12.

1971 Palaeocyclus sp. - Caldwell, p. 4 (reprint pagination).

1971 "Microcyclus" multiradiatus (Meek). - Pedder, pp. $51,53$.

1973 Microcyclas kirbyi (Meek) [sic!]. - McLaren in Gabrielse et al., part 2, p. 178.

1973 Microcycles kirbyi (Meek) [sic!]. - McLaren in Gabrielse et al., part 2, p. 215.

1975 "Microcyclus" multiradiatus (Meek). - Pedder, p. 572.

1975 "Microcyclus" multiradiatus (Meek). - Pedder in Uyeno \& Mason, p. 717.

1977 "Microcyclus" multiradiatus (Meek). - Pedder, p. 101.

1978 Devonodiscus multiradiatus (Meek). - Uyeno, p. 252. [nomen nudum]

1980 "Microcyclus" multiradiatus (Meek). - Pedder, p. 616.

non 1982 "Microcyclus" multiradiatus (Meek).-Pedder, p. 580. [= Devonodiscus latisubex Pedder]

1991 "Microcyclus" multiradiatus (Meek). - Pedder in Morrow, pp. 98, 105, 108, 120, 121.

1993 "Microcyclus" mulltiradiatus. - Pedder in Moore, tab. 4d.1, p. 153.

2017 "Microcyclus" multiradiatus (Meek). - Pedder, p. 352, text-fig. 3a, b.

Type series. - Holotype only, USNM 14552, not USNM 14952 given by Bassler (1937). In spite of photographic refiguring by Bassler, this almost smooth water-worn specimen is unsuitable as a type in modern taxonomy, especially as its occurrence data are known only as "Onion river, lat. 67 deg., long. 125 deg. Collected by R.W. McFarlane" (Meek 1868, p. 85). The name Onion probably came from J.S. Onion, a Royal Canadian Rifles officer, who worked for the Hudson's Bay Company after military service, and would have been known to MacFarlane. Onion as a name for a river in the Northwest Territories is not recognised by the Geographical Names Board of Canada. The co-ordinates given by Meek were presumably provided by MacFarlane and, if correct would place the type locality near Lac des Bois at locality 2 in 
Fig. 1 of the present paper, where the nearest dated outcrop has yielded a Cretaceous, likely Aptian, microflora (Hopkins in Cook \& Aitken 1971, p. 40). The Cretaceous of this area overlies Cambrian to Ordovician beds.

Additional material. - Two previously (Pedder 2017) illustrated GSC types 136618, 136619 from GSC Loc. C-024631. Fifteen newly illustrated types, GSC 140167-140181 from GSC Loc. C-002536. Three newly illustrated types, GSC 40964, 40965, 140183 from GSC Loc. C-012116. One newly illustrated type, GSC 140166 from GSC Loc. O-007235. One newly illustrated type, GSC 140165 from GSC Loc. O-040357. One newly illustrated type, GSC 14082 from Traid Oil D15. About 20 unillustrated and unprepared specimens from GSC Localities (in N to S order) C-002536, O-040357, C-001804, C-001800, C-075743, C-075555, C-075538, C-075539, C-003959, O-058761 and O-058665. See Fig. 1 for geographic locations, and appendix for the most detailed information available for these locations.

Diagnosis. - Species of Devonodiscus differentiated from other certain species of the genus by its consistently discoid corallum that is never cylindrical or pulley-shaped, and does not, or only very rarely includes dissepiments or other horizontal skeletal elements.

Description. - Corallum solitary, consists either of a single low disc (Figs $7 \mathrm{~K}, 8 \mathrm{H}$ ), or of several superposed discs resulting from rejuvenescences (Figs 7E, 8D). Maximum diameter of corallum c. $30.5 \mathrm{~mm}$. Maximum height of single disc $c$. $4.0 \mathrm{~mm}$ (Fig. 7D). Height of corallum following the maximum of three or four rejuvenescences $c$. $9.0 \mathrm{~mm}$ (Fig. 7E). Dimensions of the water-warn holotype, diameter $17.5 \mathrm{~mm}$, height c. $3.0 \mathrm{~mm}$, are about average for the large collection of specimens presently available for study. Epitheca with concentric delicate growth increments present on proximal surfaces of all well preserved specimens (Fig. 7G). Calice shallow. In single disc coralla, concavity of calice may be less than the convexity of the lower surface of the corallum (Fig. 8H). Cardinal fossula variable, deep and straight in holotype, deep and bent in some specimens (Fig. 7A), shallow in others (Fig. 8F), and in an extreme case the cardinal fossula is undeveloped (Fig. 8H). In a few specimens a calicular boss is present on the counter side of the periaxial region (Fig. 8G). The outer perimeter of the calice is normally broadly excert (Figs 7E, 8D), or has a downwardly sloping distal surface (Figs 7K, 8F).

Septal arrangement bilateral. Except for alar septa, protosepta discernible in specimens with corallum diameter $>7.0 \mathrm{~mm}$. Cardinal septum long, more or less straight (Fig. 7L) to moderately curved in periaxial region (Fig. 7A). Counter septum and adjacent counter-lateral septa long and almost straight. Alar septa not well differentiated in most specimens. Major metasepta variably long, minor metasepta about one third to half the length of the major metasepta. Septal edges uniform around circumference of well preserved coralla (Figs 7N, 8C). Interseptal spaces almost totally closed below the calice surface (Figs 8J, 9F). Meek (1868) counted 48 to 50 "primary" septa, i.e. protosepta as well as major metasepta in the holotype, which was the only specimen available to him. In adult specimens that have identifiable alar septa, there are 41 to 43 major metasepta. The number of major metasepta is 9 to 11 in cardinal quadrants and 10 or 11 in counter quadrants. Septal microstructure difficult to discern due to recrystallization. Carination in the outermost noncontiguous parts of septa (lower left sides of Fig. 8I, J), and weekly serrated upper surfaces of septa (Fig. 7D, K) strongly suggest that the septa are trabeculate.

Remarks. - MacFarlane's collecting for the Smithsonian Institution was for birds, eggs and mammals north of latitude $67^{\circ}$ (Hohn, 1963). Nevertheless, since MacFarlane was employed by Hudson's Bay Company at the time (1861 to 1866), he would have had opportunities to handle interesting specimens from areas such as the Sam MacRae Lake area, which has provided 15 typical specimens of Devonodiscus multiradiatus used in the present work.

Occurrence. - All specimens with precisely known occurrence data are from the middle Eifelian Eoschuchertella adoceta benthic assemblage Zone and Tortodus australis conodont Zone in either the lower Hume Formation or in lower to middle levels of the diachronous Headless Formation on the northwestern slope of the North American Craton.

\section{Devonodiscus discoideum (Soshkina, 1936) comb. nov.}

1936 Glossophyllum discoideum n.; Soshkina, pp. 67, 75, figs 80,81 .

1949 Glossophyllum discoideum Soshk. - Soshkina, pp. 152, 153, pl. 5, fig. 6, pl. 7, figs 1a-4.

1951 Glossophyllum discoideum Soshk. - Soshkina, p. 47, fig. 20.

1952 Glossophyllum discoideum Soshk. - Soshkina, p. 87, pl. 22, fig. 81 (four individual illustrations).

1955 Glossophyllum discoideum Soshkina-Spasskiy, p. 115, pl. 13, figs 1a-2d.

1962 Chonophyllum discoideum (Soshkina). - Soshkina et al., pp. 291, 293, Tetracoralla figs 6, 17a, b.

1980 Glossophyllum discoideum Soshkina. -Tsyganko, pp. 28-30, figs 1a-3.

1981 Glossophyllum discoideum Soshkina. - Tsyganko, p. 122 , pl. 51, fig. 3 , pl. 52, fig. 5, pl. 53, figs 1a-5b.

2011 Glossophyllum discoideum Soshk. - Tsyganko, pp. $110,111$. 

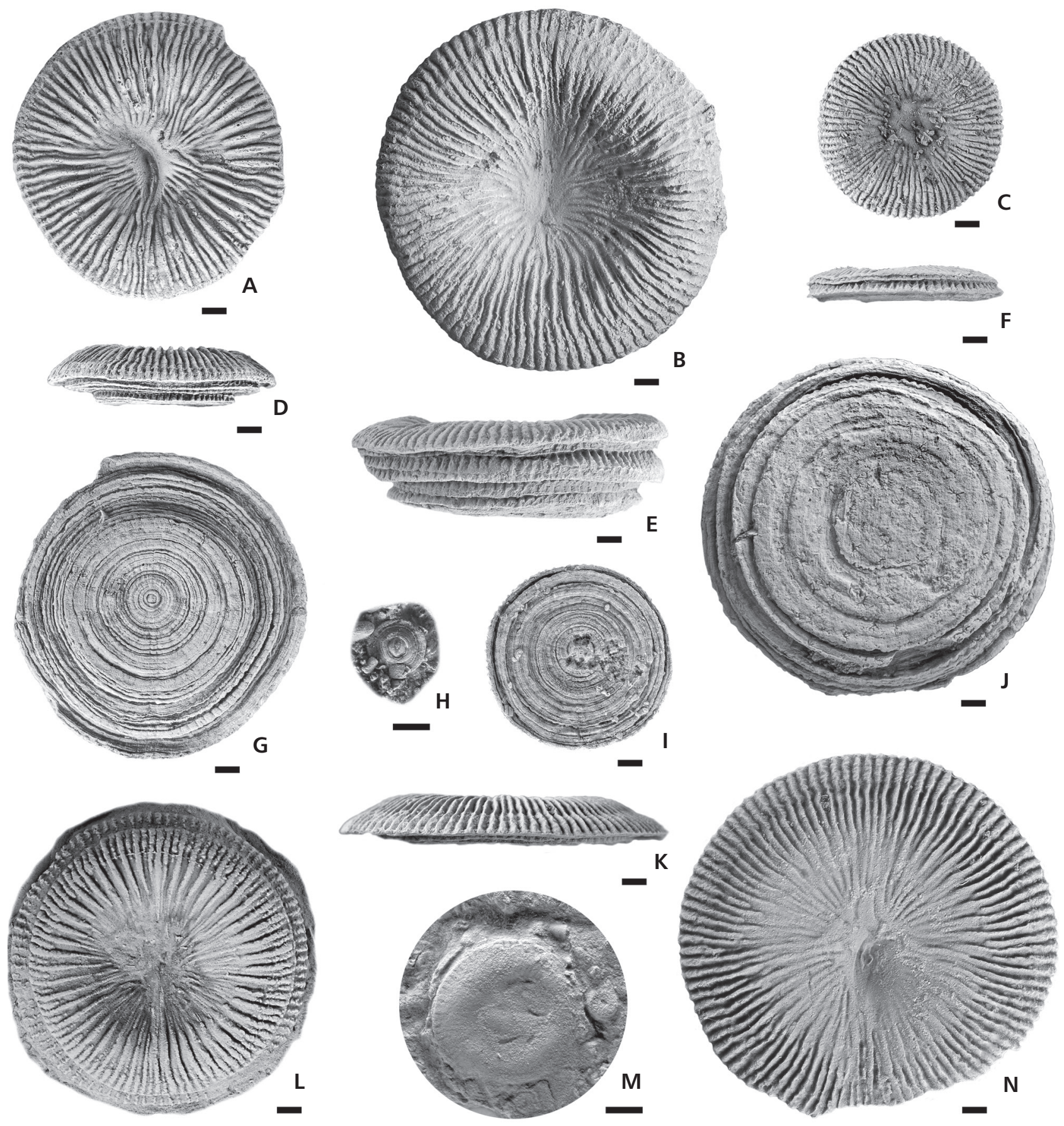

Figure 7. Devonodiscus multiradiatus (Meek) gen. nov. from lower Hume Formation, Northwest Territories, Canada. Except for K and N, from unnamed tributary of Gayna River, GSC Loc. O-040357, and L from Norman Range, GSC Loc. O-007235, all specimens are from near Sam MacRae Lake, GSC Loc. C-002536. Where possible upper views orientated to place cardinal septum on lower side of illustration; A, D, G - GSC 140171, upper, side and lower views; B, E, J - GSC 140172, upper, side and lower views; C, I - GSC 140170, upper and lower views; F - GSC 140173, side view; H - GSC 140181, under side of a very small specimen on bedding plane; K, N - GSC 140165, side and upper views; L - GSC 140166, upper view of specimen on bedding plane; M - GSC 140174, upper view of water-worn specimen on upper surface of bedding. Scale bars represent $2 \mathrm{~mm}$.

Type series. - According to Spasskiy (1955) the holotype consists of the two thin sections, numbered 438 and 439 , figured as line drawings by Soshkina in 1936. Subsequent photographic illustrations of the same two thin sections
(Soshkina 1949, pl. 7, figs 1a, b; 1952 lower two corals of pl. 22, fig. 81) strongly suggest that they are of different specimens, i.e. syntypes. Type stratum originally given as bed 2 of outcrop 8 on bank of Malyi Patok River, below 

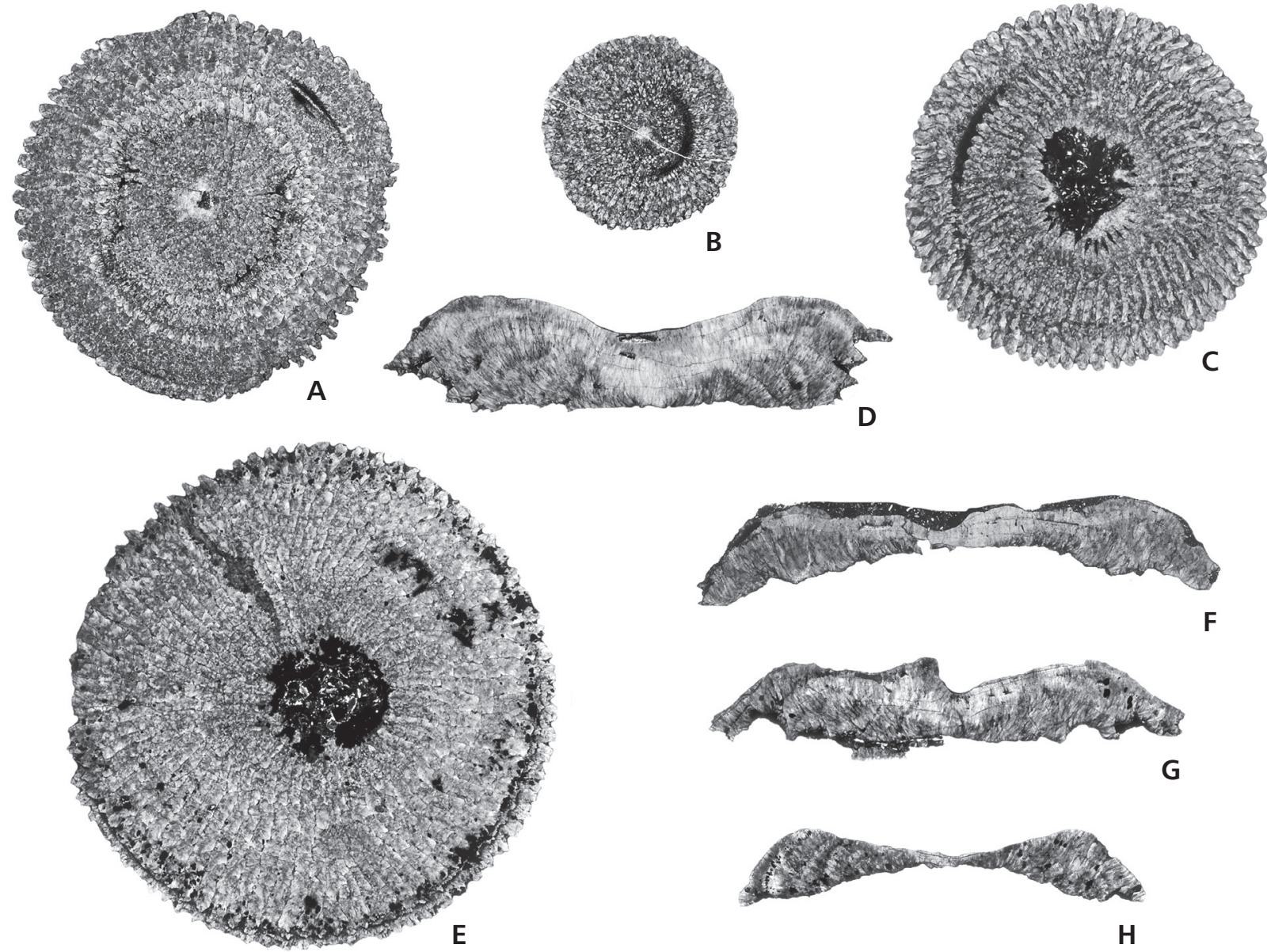

H
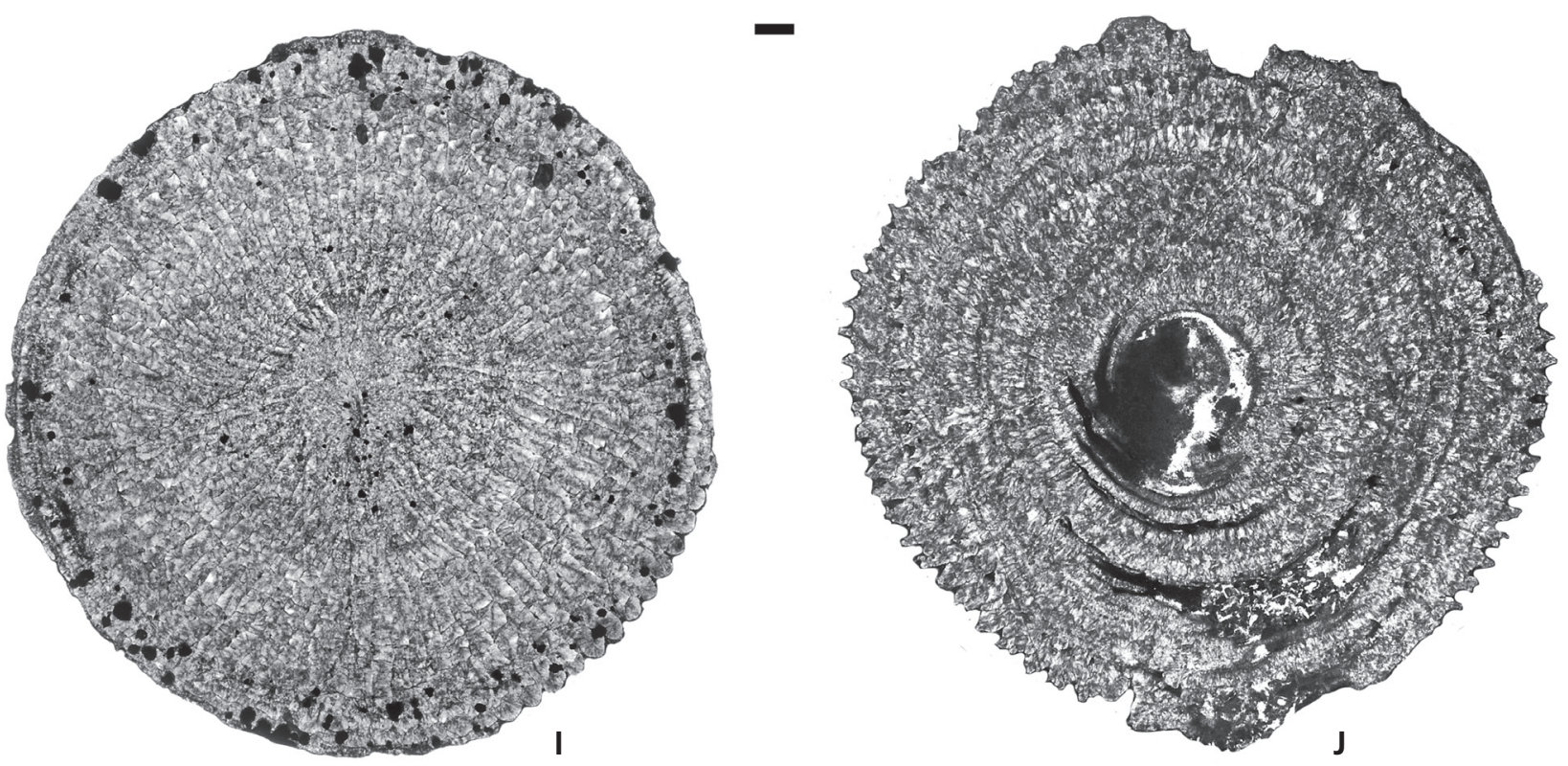

Figure 8. Devonodiscus multiradiatus (Meek) gen. nov. All from lower Hume Formation, near Sam MacRae Lake, GSC Loc. C-002536; A - GSC 140169, transverse section; B - GSC 140180, transverse section; C - GSC 140177, transverse section; D - GSC 140179, randomly oriented longitudinal section; E - GSC 140176, transverse section; F - GSC 140168, longitudinal section near cardinal-counter (left side) plane; G - GSC 140178, longitudinal section through cardinal-counter (right side) plane; H - GSC 140167, longitudinal section approximately perpendicular to cardinal-counter plane; I - GSC 140175, transverse section; J - GSC 140174, transverse section. Scale bar represents $2 \mathrm{~mm}$. 


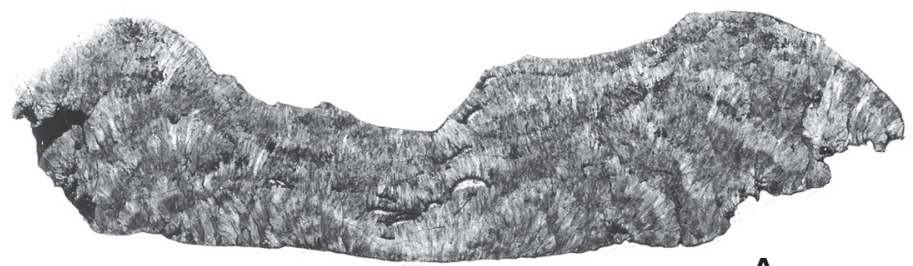

A
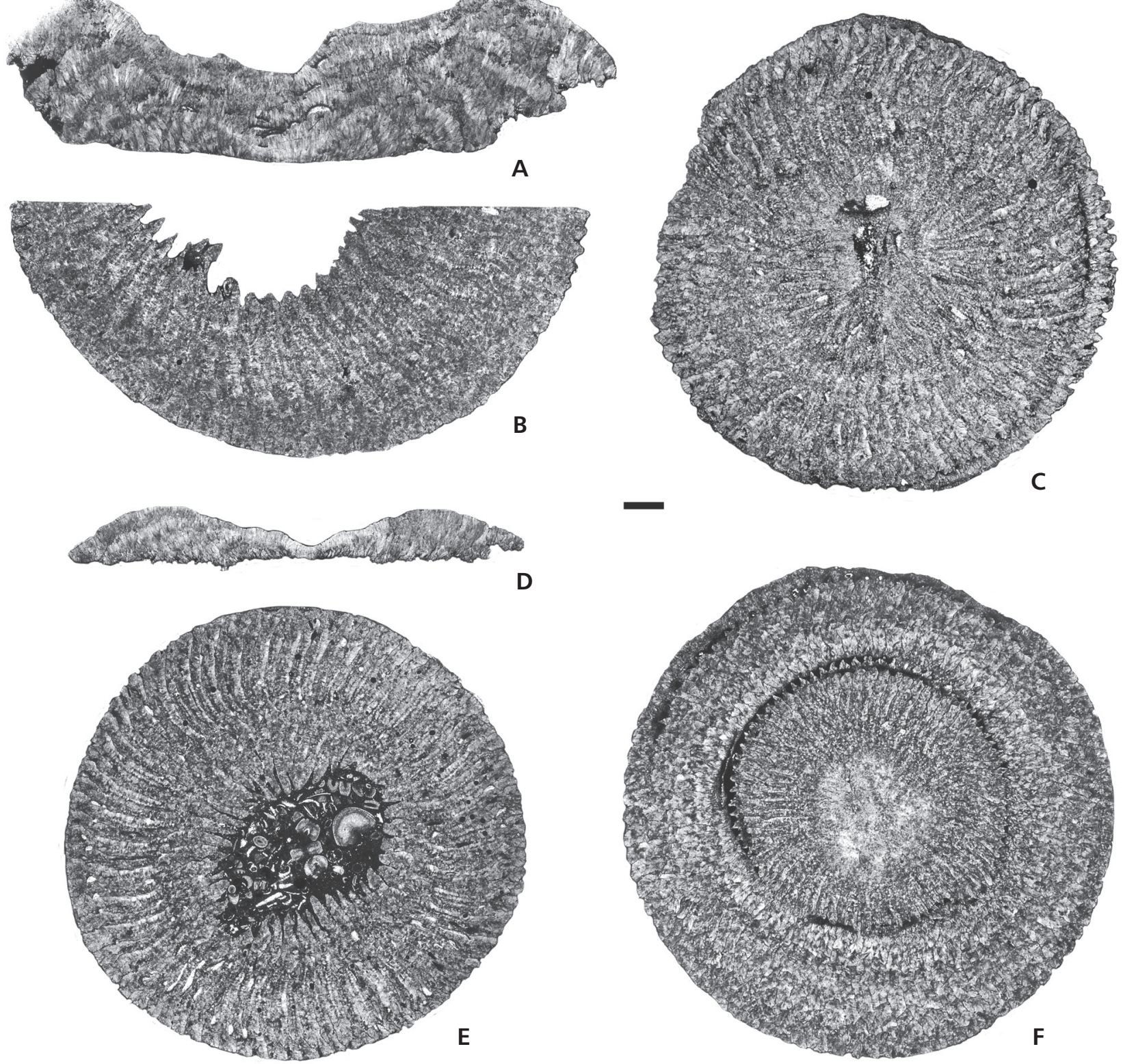

Figure 9. Devonodiscus multiradiatus (Meek) gen. nov. All from lower Hume Formation, W fork of Prohibition Creek, Norman Range, GSC Loc. C-012116. Complete transverse sections oriented to place cardinal septum at lowest point of the illustration; A, B - GSC 140183, longitudinal and part transverse section; C, E, F - GSC 40965, successive transverse sections (F lowest, E highest); D - GSC 40964, longitudinal section near perpendicular to cardinal-counter plane. Scale bar represents $2 \mathrm{~mm}$.

Gerd-kyrta Cliff, Northern Urals. Tsyganko (1981) placed Soshkina's bed 2 in the Eifelian Koyva Horizon (Russian gorizont). Repository not given.

Remarks. - Previous assignments of the species to Glossophyllum and Chonophyllum are discussed above in comments on the new genus Devonodiscus.

Occurrence. - Devonodiscus discoideum occurs on the banks of Malyi Patok and Shchugor rivers on the western side of the Northern Ural Mountains and in at least three exposures along the Us'va and Kos'va rivers on the western slope of the Central Ural Mountians (Spasskiy 1955). The species occurs in the same 40 m-thick unit as brachiopods Megastrophia uralensis (Verneuil) and Zdimir tenuicostatum (Litvinovich) in the Shchugor section (Tsyganko 2011), which suggests that it may be early rather than younger Eifelian age at that locality. 
?Devonodiscus wellingtonensis (Packham, 1954) comb. nov.

Figure $10 \mathrm{~A}-\mathrm{G}$

1954 Hadrophyllum wellingtonense n.; Packham, p. 121, figs a-c.

?partim 1968 Hadrophyllum wellingtonense. - Strusz, tables pp. 128, 131 (occurrence in Mount Etna Lst. questionable).

1969 Hadrophyllum wellingtonense. - Packham, p. 138.

Type series. - Holotype, originally University of Sydney collection 7100, now reposited F. 85211 in the Australian Museum, Sydney. Four topotypic paratypes, same repositories, originally 7101-7104, now all four registered F. 85212. Stratum and locality given as Garra Beds in Portion 50 (error for Portion 170) Parish of Curra, east bank of Curra Creek, three hundred yards $(274.3 \mathrm{~m}$ ) south of where the Wellington-Arthurville road crosses Curra Creek, New South Wales. Age of the type occurrence was originally thought to be possibly early Couvinian, close to the Lower-Middle Devonian boundary, however it is mostly likely to be as old as Pragian (Strusz et al. 1972, chart; Mawson et al. 1989, fig. 2; Murphy 2005, p. 189).

Additional material. - Six approximate topotypes, after preparation AMFT 15452-15458 and AMF 144771 from Garra Formation, isolated outcrop in Curra Creek, Portion 170, Parrish of Curra, about $9 \mathrm{~km}$ south of Wellington on the Molong-Monaro Terrane, southeastern Australia. Collected by the present author in early or middle 1960s. Field notes are no longer available, nevertheless the occurrence in fine grained calcarenites is likely to be in calcarenites shown 100-400 m below top of the formation in the right of three stratigraphic sections figured on page 86 of Strusz's 1965 paper.

Description. - Corallum discoid, slightly to markedly elliptical in plan view with greatest and smallest diameters 18 and $15 \mathrm{~mm}$. Clearly visible epithecal growth increments on the underside may be concentric in early stages (diameter $<8 \mathrm{~mm}$ ), but are normally weakly to strongly excentric in adult stages. Height of adult corallum measured from flat early base to highest part of everted calice $6.2 \mathrm{~mm}$. Septal symmetry is bilateral with narrow cardinal and alar fossulae. The long cardinal septum extends to the calicular boss over the calice floor. In the upper everted calice region the cardinal septum is only slightly longer than the closest major septa. Two septa that appear to be cardinal (possibly counter-laterals of Hudson 1936 according to Packham) are more or less equally long (Fig. 10F). Alar septa are clear in Packham's drawing of the holotype (his fig. a) but are not easy to distinguish in other specimens. Because of the imperfect preservation septal counts are not easy to estimate. Packham reported that there are 52-56 septa in mature individuals. The present author has counted 7 major metasepta in each cardinal and counter quadrant.

\section{?Devonodiscus clebroseptatus (Kravtsov, 1975) comb. nov.}

1968 Glossophyllum clebroseptatum Krav. - Kravtsov in Cherkesova et al., p. 21. [nomen nudum]

1975 Glossophyllum clebroseptatum n.; Kravtsov in Besprozvannykh et al., pp. 73, 104, pl. 21, figs $2 \mathrm{a}-3$.

1994a Glossophyllum clebroseptatum Krav. - Lakhov, G.V. or Kravtsov, A.G. in Cherkesova, p. 17 footnote.

1994a Glossophyllum clebroseptatum Krav. - Cherkesova, p. 21.

2007 "Glossophyllum" clebroseptatum Kravtsov. - Pedder, appendix c, p. 5.

Type series. - Five specimens from locality 770 (Cherkesova 1994a, fig. 11), about $40 \mathrm{~km}$ above the mouth of Tareya River, south Taimyr fold zone, Russia. The holotype is specimen 419/12 illustrated in Besprovannykh et al. (1975, pl. 21, fig. 2a-v), repository not given but likely to be in Sankt-Peterburg. The types include specimens from both the Daksa and underlying Tolbato beds at locality 770. Kravtsov's description and Cherkesova's (1994a) loose figure 12 imply that the holotype is from bed 770$10 \mathrm{~b}$, which is about $28 \mathrm{~m}$ above base and $45 \mathrm{~m}$ below top of the Daksa beds. The lowest established occurrence of the icriodid conodont Vjaloviodus taimyricus in the same section is $12 \mathrm{~m}$ or less above the type stratum (Cherkesova 1994a, loose fig. 12). From data provided by the distribution of conodonts V. taimyricus (Kuz'min 1967, Gagiev 1984, Sobolev 1994) and Polygnathus dehiscens sensu Sobolev (1994), and brachiopods (Cherkesova 1994b, Talent et al. 2001) in the Tareya River succession, the type stratum of "Glossophyllum" clebroseptatum is either upper Lochkovian or lower Pragian.

Cherkesova, who authored the measurement of section 770, recorded the presence of Glossophyllum clebroseptatum in unit 770-10 only (Besprozvannykh et al. 1975, p. 104). Two or three specimens of the five types, depending on whether sectioned specimen illustrated in figure $2 \mathrm{~g}$ really is the same as the unprepared specimen illustrated in figure 2a-v, came from the Daksa beds. And two specimens apparently came from unit 770-7 or 8, high in the underlying Tolbato beds (Cherkesova 1994a, fig. 9). From brachiopod data, these are either Lochkovian (Talent et al. 2001, p. 87) or lower Pragian (Al'khovik \& Baranov 2001, supplement table 1, list 9). 

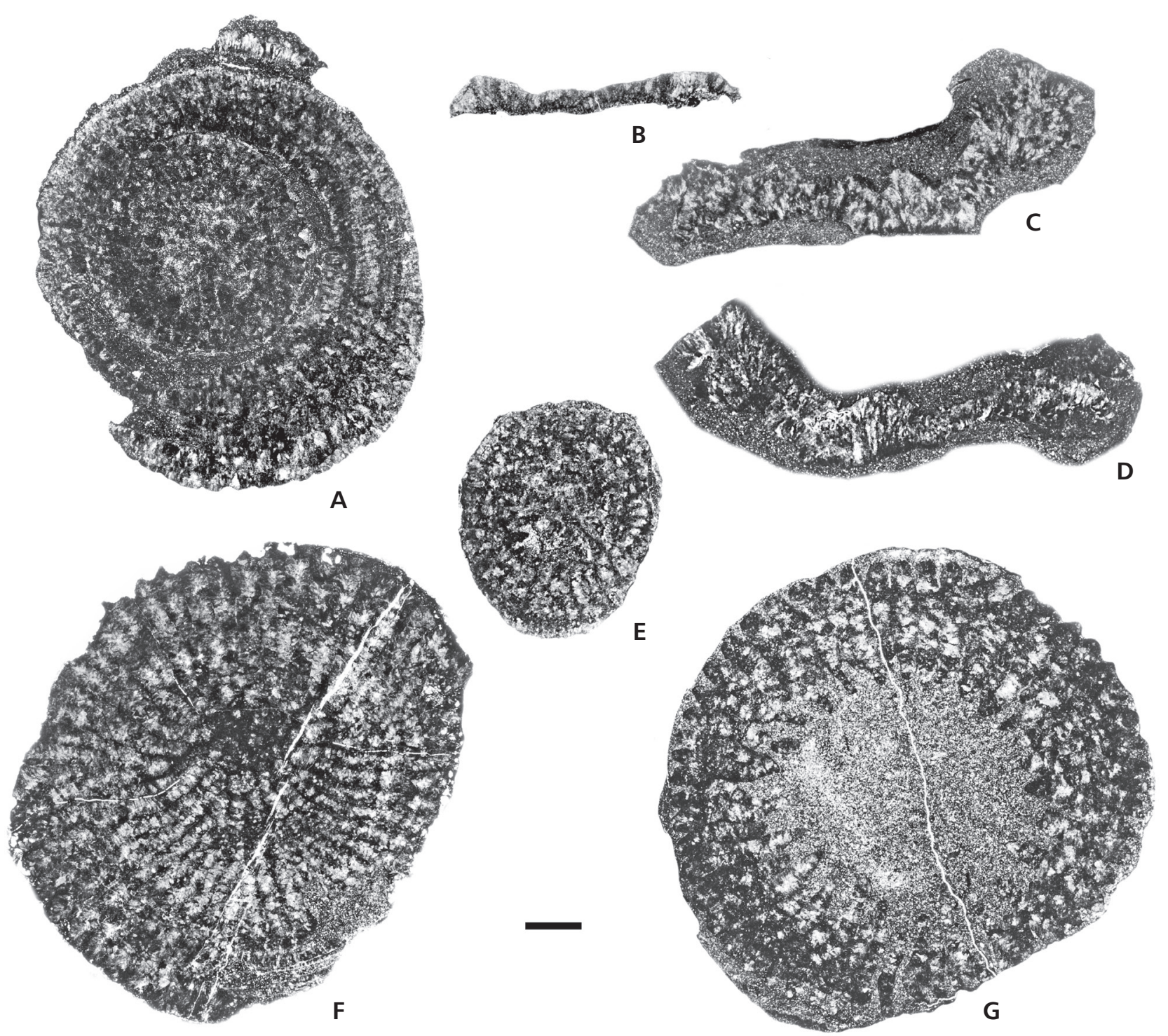

Figure 10. ?Devonodiscus wellingtonensis (Packham). Approximate topotypes, Garra Beds, Curra Creek, Portion 170, Parish of Curra, MolongMonaro Terrane, SE Australia. As far as possible, illustrations of transverse sections oriented to place the cardinal septum on the lower side of the illustration. Longitudinal sections oriented so that the early base of the discoid corallum is horizontal; A - AMFT 15452, transverse section; B - AMFT 15453 , longitudinal section of an immature corallum, randomly orientated in respect to the cardinal-counter plane; C, D - AMFT 15454, 15455, longitudinal sections close to cardinal-counter plane, cardinal side on left in C, on right in D; E - AMFT 15456, transverse section of immature specimen; F - AMFT 15457, transverse section near base of adult corallum; G - AMFT 15458, transverse section through calice of adult corallum. Scale bar represents $2 \mathrm{~mm}$.

Remarks. - Kravtsov's descriptions and illustrations of the holotype indicate that it is a discoid coral, slightly elliptical in plan view with greatest and smallest diameters 35 and $32 \mathrm{~mm}$. The lower surface shows early (diameter $<10 \mathrm{~mm}$ ) growth increments to be concentric and later increments to be excentric. In upper view, bilateral septal arrangement and a narrow cardinal fossula are clearly visible. The position, but not the morphology of the cardinal septum is clear. The counter septum is barely distinguishable from the adjacent metasepta. One of the alar septa is more distinguishable than the other.
An outstanding feature of the species is the presence of a prominent calicular boss of fused septal ends, centred in the cardinal-counter plane on the counter side of the calice.

Septa are in two orders and except for their most distal edges are in contact throughout the corallum. Although lines separating fused septa are mostly just visible in figure $2 \mathrm{~g}$ of Kravtsov's plate, septa, as Kravtsov noted, are difficult to count. In one specimen, $20-25 \mathrm{~mm}$ in diameter, from the Daksa beds, he estimated that there are no less than 42 major septa. An estimate from the 
illustration of the upper surface of the holotype, suggests there are 9 or 10 major septa in each cardinal quadrant and 17 or 18 major septa in each counter quadrant. The only "longitudinal" section illustrated by Kravtsov (pl. 21 , fig. 3) is a tangential section from the Tolbato beds. It is difficult to interpret but certainly shows small variably inwardly inclined dissepiments.

\section{Summary and conclusions}

Two questionably synonymous discoid corals, one from northwestern Canada, the other from northeastern Alaska were named by Meek in 1868. Both were based on a single specimen. The type of one of these species, Palaeocyclus kirbyi, is lost and its type stratum and locality uncertain. The type of the other species, Combophyllum multiradiatum, is extant but its type locality is even more uncertain.

Markov (1923) erected a species named Actinocystis versiformis from supposed Middle Devonian beds of the Western Ural Mountains. After preparation and study of probable topotypes in the Geological Survey of Canada collections the species is assigned to Digonophyllum. Markov believed individual specimens of his species probably began life in a low energy lagoon-type environment and developed as a discoid coral. If, however the depth of water increased, the coral would produce a much taller cylindrical corallum. He placed figures 2 and 9 of his plate 6 to emphasize this point.

The Microcyclinae of Plusquellec (2006) are separated from the Hadrophyllidae to which they were previously attached, and are raised to family rank. A new family and genus, Devonodiscidae and Devonodiscus, are erected for northwestern Canadian corals that have been associated with Microcyclus for more than 80 years and for a species from the northern Urals that has been assigned to Glossophyllum for a similar period. Coralla of Devonodiscus latisubex sp. nov., the type species of the genus, and $D$. discoideum (Soshkina, 1936) show as much or more morphological variation as Digonophyllum versiforme. Morphological variation in two species of Devonodiscus suggests that some individuals needed to rapidly modify their coralla to allow vertical growth to continue after any bedding plane disturbance. Combophyllum multiradiatum Meek shows much less morphological variation, but is included in Devonodiscus because of its septal morphology and microstructure.

High resolution stratigraphy reveals that in northwestern Canada Devonodiscus latisubex is confined to the deepest facies of the Carinatrypa dysmorphostrota benthic assemblage Zone and to the Tortodus kockelianus and possibly lowermost overlying Polygnathus xylus ensensis conodont zones, and is a reliable benthic fossil index to the upper Hume Formation. Devonodiscus multiradiatus is confined to the Eoschuchertella adoceta benthic assemblage Zone and to the upper Tortodus australis and probably lower Tortodus kockelianus conodont zones (Uyeno et al. 2017) and is a reliable benthic fossil index to the middle Eifelian in both the Hume and Headless formations.

The close similarity between Devonodiscus latisubex and $D$. discoideum and the known distribution of other Eifelian species of the genus add to Blodgett \& Pedder's (2018) brachiopod evidence that northwestern Canada, southern Novaya Zemlya and Northern Urals belonged to the same faunal province in late Eifelian time.

\section{Acknowledgements}

The following are thanked for their help making the present contribution possible. Glen Edwards for photography and assembly required for Figs 2-10. Doug Lemay for vector graphics for Fig. 1. Michelle Coyne and Richard Fontaine for help concerning GSC collections, and to the GSC management for use of a thin-section laboratory during my emeritus status with the GSC. Mathew McCurry, Ross Pogson, and Patrick Smith for information about specimens reposited in the Australian Museum, Sydney. The late Allen Ormiston while employed by Pan American Petroleum Corporation for identification of trilobites. Yves Plusquellec, University of Bretagne Occidentale, Brest for opinions and data regarding Devonodiscus. Robert Oleson, previously Public Relations Officer of the Hudson's Bay Company, Winnipeg and Kristina Kwiatkowski, Natural Resources Canada for information concerning the possible whereabouts of "Onion river", the type locality of $D$. multiradiatus. Critical readers Ross A. McLean, Yves Plusquellec and editor Štěpán Manda are sincerely thanked for numerous helpful suggestions concerning the original submitted manuscript. The author alone is responsible for any remaining errors.

\section{References}

Adrianova, K.I. 1975. Koyvenskiy gorizont (svita), 233. In ZANinA, I.E. \& LiKHAREv, B.K. (eds) Stratigraficheskiy slovar' SSSR, Kembriy, Ordovik, Silur, Devon. Nedra, Leningrad.

AL'кhoviK, T.S. \& Baranov, V.V. 2001. Stratigrafiya nizhnego devona Vostochnoy Yakutii (Severo-Vostok Rossii). 149 pp. Rossiyskaya Akademiya Nauk, Sibirskoe Otdelenie, Yakutsk.

ArtyushKova, O.V., Maslov, V.A., Pazukhin, V.N., Kulagina, E.I., Tagarieva, R.Ch., Mizens, L.I. \& Mizens, A.G. 2011. Devonian and Lower Carboniferous type sections of the western South Urals. Biostratigraphy, Paleogeography and Events in Devonian and Lower Carboniferous. Preconference Field Excursion Guidebook. 92 pp. Russian Academy of Sciences, Ufa.

Bassett, H.G. 1961. Devonian stratigraphy, central Mackenzie River region, Northwest Territories, Canada, 481-498. In 
RaAsch, G.O. (ed.) Geology of the Arctic 1. University of Toronto Press, Toronto.

Bassler, R.S. 1937. The Paleozoic rugose coral family Paleocyclidae. Journal of Paleontology 11(3), 189-201.

Besprozvannykh, N.I., Dubatolov, V.N., Kravtsov, A.G., Latypov, Yu.Ya. \& SpasskiY, N.YA. 1975. Devonskie rugozy Taymyro-Kolymskoy provintsii. Akademiya Nauk SSSR, Sibirskoe Otdelenie, Trudy Instituta Geologii i Geofiziki 228, $1-172$.

Birenheide, R. 1964. Die "Cystimorpha" (Rugosa) aus dem Eifeler Devon. Abhandlungen der Senckenbergischen Naturforschenden Gesellschaft 507, 1-120.

BIRENHEIDE, R. 1969. Typen mittel- und oberdevonischer Rugosa aus der Sammlung Goldfuss. Senckenbergiana lethaea 50(1), $37-55$.

BiRENHEIDE, R. 1971. Untersuchungen an Microcyclus clypeatus (Goldfuss) [Rugosa; Mitteldevon]. Senckenbergiana lethaea 52(5-6), 501-527.

Blodgett, R.B. \& Pedder, A.E.H. 2018. The presence of the genus Zdimirella Cherkesova (Devonian Brachiopoda) in North America (Arctic Canada). Fossil Record 6, New Mexico Museum of Natural History and Science Bulletin 79, $75-82$.

Bul'VANKer, E.Z. 1958. Devonskie chetyrekhluchevye korally okrain Kuznetskogo basseyna. 93 pls \& 212 pp. \& VSEGEI, Leningrad.

Bul'vanker, E.Z. 1965. Pervye dannye o devonskikh rugozakh Severo-Vostoka SSSR, 54-58. In Sokolov, B.S. \& IvanovSKIY, A.B. (eds) Rugozy paleozoya SSSR. Izdatel'stvo Nauka, Moskva.

Caldwell, W.G.E. 1964. The nomenclature of the Devonian formations in the lower Mackenzie River valley. Bulletin of Canadian Petroleum Geology 12(3), 611-622.

Caldwell, W.G.E. 1971. The biostratigraphy of some Middle and Upper Devonian rocks in the Northwest Territories: an historical review. The Musk-Ox Publication 9, 15-34. [reprints paginated 1-20]

Chatterton, B.D.E. 1978. Aspects of late Early and Middle Devonian conodont biostratigraphy of western and northwestern Canada, 161-231. In Stelck, C.R. \& Chatterton, B.D.E. (eds) Western and arctic Canadian biostratigraphy. Geological Association of Canada Special Paper 18.

Cherkesova, S.V. 1994a. Obshchaya stratigraficheskaya kharakteristika nizhnedevonskikh otlozheniy tareyskogo oporngo razreza, 7-32. In Cherkesova, S.V., KaratayuteTalitaA, V.N. \& Matukhin, R.G. (eds) Stratigrafiya i fauna nizhnedevonskikh otlozheniy tareyskogo opornogo razreza (Taymir). Nedra, Sankt-Peterburg.

Cherkesova, S.V. 1994b. Brakhiopody, 33-90. In Cherkesova, S.V., Karatayute-TalitaA, V.N. \& Matukhin, R.G. (eds) Stratigrafiya i fauna nizhnedevonskikh otlozheniy tareyskogo opornogo razreza (Taymir). Nedra, Sankt-Peterburg.

Cherkesova, S.V., Patrunov, D.K., Smirnova, M.A., Kuz'min, A.M., Kravtsov, A.G. \& Nekhorosheva, L.V. 1968. Tareyskiy nizhnedevonskiy opornyy razrez. (Tsentral'nyy Taymir). Uchenye Zapiski, Paleontologiya i Biostratigrafiya $22,5-35$.
Cook, D.G. \& Aitken, J.D. 1971. Geology, Colville Lake maparea and part of Coppermine map-area (96 NW and NE, part of $86 \mathrm{NW}$ ) Northwest Territories. Geological Survey of Canada Paper 70-12, i-vi, 1-42. [includes map no. 12-1970]

CRICKMAY, C.H. 1960a. The older Devonian faunas of the Northwest Territories. 21 pp. Evelyn de Mille Books, Calgary.

Crickmay, C.H. 1960b. Studies of the western Canada Stringocephalinae. Journal of Paleontology 34(5), 874-890.

Douglas, R.J.W. \& Norris, D.K. 1960. Virginia Falls and Sibbeston Lake map-areas, Northwest Territories 95F and 95G. Geological Survey of Canada Paper 60-19, 1-26. [includes maps 22-1960, 23-1960] DOI 10.4095/101200

Douglas, R.J.W. \& Norris, D.K. 1961. Camsell Bend and Root River map-areas., District of Mackenzie, Northwest Territories 95J and K. Geological Survey of Canada Paper 61-13, 1-36. [includes maps 22-1961, 23-1961] DOI $10.4095 / 101102$

Elkin, E.A., Gratsianova, R.T., Bakharev, N.K. \& ZheltoNOGOVA, V.A. 1985. O sopostavlenii skhem raschleneniya srednego devona Salaira i Urala, 121-132. In KAMALETdinov, M.A. \& Rzhonsnitskaya, M.A. (eds) Sredniy devon SSSR, ego granitsy i yarusnoe raschlenenie. Nauka, Moskva.

Ermakova, K.A. 1964. Nekotorye srednedevonskie korally Volgo-Uralskoy oblasti, 94-123. In Semikhatova, S.V. (ed.) Fauna paleozoya Volgo-Uralskoy neftegazonosnoy provintsii. Vsesoyuznyy Nauchno-Issledovatel'skiy Geologogorazvedochnyy Neftyanoy Institut Trudy 43.

FARrell, J.R. 1992. The Garra Formation (Early Devonian: late Lochkovian) between Cumnock and Larras Lee, New South Wales, Australia: stratigraphic and structural setting, faunas and community sequence. Palaeontographica 222(1-3), $1-41$.

Farrell, J.R. 2003. Late Přidoli, Lochkovian and early Pragian conodonts from the Gap area between Larras Lee and Eurimbla, central western NSW, Australia. Courier Forschungsinstitut Senckenberg 245, 107-181.

Fontaine, H. 1961. Les Madréporaires paléozoïques du ViêtNam, du Laos et du Cambodge. Archives Géologiques du Viêt-Nam 5, 1-276 (v. 1), pls 1-35 (v. 2).

Fraunfelter, G.H. \& Engstrom, J.C. 1970. Development of the rugose coral Microcyclus discus Meek and Worthen from the Devonian of Illinois and Missouri. Journal of Paleontology 44(6), 1085-1091.

FreCh, F. 1911. China. Ergebnisse eigener Reisen und darauf gegründeter Studien von Ferdinand Freiherrn v. Richthofen 5 , xii +289 pp. Verlag von Deitrich Reimer (Ernst Vohsen), Berlin.

Gabrielse, H., Blusson, S.L. \& Roddick, J.A. 1973. Geology of Flatt River, Glacier Lake, and Wrigly Lake map-areas, District of Mackenzie and Yukon Territory. Geological Survey of Canada Memoir 366, part I: pp. 1-153, part II: pp. 1-268. [date of imprint 1972]

Gagiev, M.Кн. 1984. Novye devonskie ikriodidnye konodonty. Paleontologicheskiy Zhurnal 1984(1), 105-108.

Goldfuss, G.A. 1826-1833. Petrefacta Germaniae, pp. 12 unnumbered + 1-76 (1826), pp. 77-164 (1829), pp. 165-240 (1831), pp. 241-253 (1833). Arnz \& Comp., Düsseldorf. 
HiLl, D. 1981. Coelenterata, part F, supplement 1, Rugosa and Tabulata, F1-F378 (v. 1), F379-F762 (v. 2). In Teichert, C. (ed.) Treatise on Invertebrate Paleontology. Geological Society of America \& University of Kansas Press, Lawrence.

Hohn, E.O. 1963. Roderick MacFarlane of Anderson River and Fort. The Beaver, winter 1963, 22-29.

House, M.R. \& Gradstein, F.M. 2004. The Devonian Period, 202-221. In Gradstein, F.M., OgG, J.G. \& Smith, A.G. (eds) A Geologic time scale 2004. Syndicate of the University of Cambridge.

Hume, G.S. 1923. Geology of the Norman oil fields and a reconnaissance of a part of Liard River. Geological Survey of Canada Summary Report 1922B, 47-64. [includes map no. 1977] DOI 10.4095/103147

International Commission on Zoological Nomenclature 1999. International Code of Zoological Nomenclature, edition 4. xxix $+306 \mathrm{pp}$. International Trust for Zoological Nomenclature, London.

IvanIYA, V.A. 1965. Devonskie korally Rugosa Sayno-Altayskoy gornoy oblasti. 398 pp. Izdatel'stvo Tomskogo Universiteta, Tomsk.

IvaniYa, V.A. \& Cherepnina, S.K. 1986. Devonskie korallyrugozy Zapadnoy Sibiri atlas-opredelitel'. 136 pp. Izdatel'stvo Tomskogo Universiteta, Tomsk.

Joplin, G.A. \& Culey, A.G. 1938. The geological structure and stratigraphy of the Molong-Manildra district. Journal and Proceedings of the Royal Society of New South Wales 71(4), 267-281.

Khalymbadzha, V.G. \& Chernysheva, N.G. 1990. Eifel'skiy yarus na Zapadnom sklone Urala, 13-17. In KHALYMBADZHA, V.G. (ed.) Konodonty Eyfel'skogo yarusa SSSR. Izdatel'stvo Kazanskogo Universeteta, Kazan'.

Klapper, G. \& Johnson, J.G. 1980. Endemism and dispersal of Devonian conodonts. Journal of Paleontology 54(2), 400-455.

Kozlov, M.S. \& Dubatolov, V.N. 1994. Middle-Paleozoic stratigraphy of southwestern Altai. Russian Geology and Geophysics 35(12), 18-29. [original Geologiya i Geofizika pagination 18-36]

Kravtsov, A.G. 1963. Rannedevonskie chetyrekhluchevye korally s reki Tarei (Tsentral'nyy Taymir). Uchenye Zapiski, Paleontologiya i Biostratigrafiya 3, 5-49.

KuZ'MIN, A.M. 1967. Pervaya nakhodka konodontov v nizhnedevonskikh otlozheniyakh Tsentral'nogo Taymira. Uchenye Zapiski, Paleontologiya i Biostratigrafiya 20, 52-57.

Lang, W.D., Sмith, S. \& Thomas, H.D. 1940. Index of Palaeozoic coral genera. 231 pp. British Museum (Natural History), London.

LE MaîtRe, D. 1952. La faune du Dévonien inférieur et moyen de la Saoura et des abords de l'Erg el Djemel (Sud-ouranais). Matériaux pour la Carte géologique de l'Algérie, série 1 Paléontologie 12, 1-170. Impimerie SILIC, Lille.

Lenz, A.C. \& Pedder, A.E.H. 1972. Lower and Middle Paleozoic sediments and paleontology of Royal Creek and Peel River, Yukon, and Powell Creek, N.W.T. XXIV International Geological Congress, Guidebook Field Excursion A14, 1-43.

Lin, B.-Y., Xu, S.-Y., Jia, H.-Z., Guo, S.-Z., Ouyang, X., Wang, Z.-J., Ding, Y.-J., CaO, X.-D., Yan, Y.-Y. \& Chen,
H.-C. 1995. Monograph of Palaeozoic corals. Rugosa and Heterocorallia. vii +778 pp. Geological Publishing House, Beijing. [in Chinese with English abstract]

Ludvigsen, R. \& Perry, D.G. 1975. The brachiopod Warrenella in the Lower and Middle Devonian formations of northwestern Canada. Geological Survey of Canada Bulletin 235, 59-106. DOI 10.4095/103986

LÜtTe, B.-P. 1987. Glossophylllum-Arten aus dem MittelDevon der Eifel (Rugosa; Rheinisches Schiefergebirge. Senckenbergiana lethaea 67(5-6), 433-457.

Lyashenko, A.I. 1964. Novye vidy devonskikh brakhiopod Russkoy platformy i Zapadnogo sklona Urala, 3-57. In Semikhatova, S.V. (ed.) Fauna paleozoya Volgo-Uralskoy neftegazonosnoy provintsii. Vsesoyuznyy Nauchno-Issledovatel'skiy Geologogorazvedochnyy Neftyanoy Institut Trudy 43.

Mansuy, H. 1916. Faunes paléozoïques du Tonkin septentrional. Mémoires du Service Géologique de l'Indochine 5(4), 1-23.

Markov, K.V. 1923. K izucheniyu korallov kal'tseolevogo gorizonta zapadnogo sklona Urala. Ezhegodnik Russkogo Paleontologicheskogo Obshchestva 3(1921), 35-41.

Mawson, R., Talent, J.A., Bear, V.C., Benson, D.S., Brock, G.A., Farrell, J.R., Hyland, K.A., Pyemont, B.D., Sloan, T.R., Sorentino, L., Stewart, M.I., Trotter, J.A., Wilson, G.A. \& Simpson, A.G. 1989. Conodont data in relation to resolution of stage and zonal boundaries for the Devonian of Australia, 485-527. In McMillan, N.J., Embry, A.F. \& Glass, D.J. (eds) Devonian of the World 3. Canadian Society of Petroleum Geologists, Calgary.

McLaren, D.J. 1962. Middle and early Upper Devonian rhynchonelloid brachiopods from western Canada. Geological Survey of Canada Bulletin 86, 1-122.

DOI 10.4095/100604

McLean, R.A. 1976. Middle Devonian cystiphyllid corals from the Hume Formation, northwestern Canada. Geological Survey of Canada Bulletin 274, 1-80.

Meek, F.B. 1868. Remarks on the Geology of the valley of Mackenzie River, with figures and descriptions of Fossils from that region, in the Museum of the Smithsonian Institution, chiefly collected by the late Robert Kennicott, Esq. Transactions of the Chicago Academy of Sciences 1(1), 61-114. [date of imprint 1867]

Meek, F.B. \& Worthen, A.H. 1868. Fossils of the Hamilton Group. Geological Survey of Illinois 3(2), 419-449.

Milne Edwards, H. \& Haime, J. 1849. Mémoire sur les Polypiers appartenant à la famille des Oculinides, au groupe intermédiaire des Pseudastréides et à la famille des Fongides. Comptes Rendus Hebdomadaires des Séances de l'Academie de la Sciences, Paris 29, 67-73.

Milne Edwards, H. \& Haime, J. 1850-1855. A monograph of the British fossil corals. i-1xxxv, pp. 1-72 (1850), pp. 73-146 (1851), pp. 147-210 (1852), pp. 211-244 (1853), pp. 245-322 (1855, imprint 1854). Palaeontolographical Society, London.

Moore, P.F. 1993. Subchapter 4D Devonian, 150-201. In Sтотт, D.F. \& Aitken, J.D. (eds) Sedimentary cover of the craton in Canada. Geology of Canada, no. 5. Geological Survey of Canada. 
Morrow, D.W. 1991. The Silurian-Devonian sequence in the northern part of the Mackenzie Shelf, Northwest Territories. Geological Survey of Canada Bulletin 413, 1-121.

DOI 10.4095/132170

Murphy, M.A. 2005. Pragian conodont zonal classification in Nevada, western North America. Revista Española de Paleontología 20(2), 177-206.

Nicholson, H.A. \& Lydekker, R. 1889. A manual of palaeontology, edition 3, 1. xviii +885 pp. William Blackwood and Sons, Edinburgh \& London.

Noble, J.P.A. \& Ferguson, R.D. 1971. Facies and faunal relations at edge of early Mid-Devonian carbonate shelf South Nahanni River area, N.W.T. Bulletin of Canadian Petroleum Geology 19(3), 570-588.

Packham, G.H. 1954. A new species of Hadrophyllum from the Garra Beds at Wellington, N.S.W. Journal and Proceedings of the Royal Society of New South Wales 87(3), 121-123.

PaскнAм, G.H. (ed.) 1969. The geology of New South Wales. Journal of the Geological Society of Australia 16(1), i-xx, 1-654. DOI 10.1080/14400956908527964

Pedder, A.E.H. 1971. Dohmophyllum and a new related genus of corals from the Middle Devonian of northwestern Canada. Geological Survey of Canada Bulletin 197, 37-77.

Pedder, A.E.H. 1975. Revised megafossil zonation of Middle and lowest Upper Devonian strata, central Mackenzie Valley. Geological Survey of Canada Paper 75-1A, 571-576. DOI 10.4095/104647

Pedder, A.E.H. 1977. Corals of the Lower/Middle and Middle/ Upper Devonian boundary beds of northern and western Canada, 99-106. In Murphy, M.A., Berry, W.B.N. \& Sandberg, C.A. (eds) Western North America: Devonian. University of California Riverside Campus Museum Contribution 4.

Pedder, A.E.H. 1980. Devonian corals of late Eifelian age from the Ogilvie Formation of Yukon Territory. Canadian Journal of Earth Sciences 17(5), 594-616. DOI 10.1139/e80-058

PedDer, A.E.H. 1982. Chostophyllum, a new genus of charactophyllid corals from the Middle Devonian of western Canada. Journal of Paleontology 56(3), 559-582.

Pedder, A.E.H. 2007. Zoogeographic data from studies of Paleozoic corals of the Alexander terrane, southeastern Alaska and British Columbia, 29-57, appendix C 1-45. In HagGart, J.W., Enkin, R.J. \& Monger, J.W.H. (eds) Paleogeography of the North American Cordillera: Evidence for and against larger-scale displacements. Geological Association of Canada Special Paper 46. [date of imprint 2006]

Pedder, A.E.H. 2017. Benthic biostratigraphy of the upper Eifelian (Devonian) Hume Formation at Hume River (type locality), northern Mackenzie Mountains, Northwest Territories, Canada. Stratigraphy 14(1-4), 349-364.

DOI 10.29041/strat.14.1-4.349-364

Plusquellec, Y. 1972. Révision du genre Microcyclus Meek et Worthen 1868 (Tétracoralliaire). Annales de la Société Géologique du Nord 91(2), 129-139.

Plusquellec, Y. 2005. Hadrophyllum asturicum n. sp., Rugosa de Dévonien de la Chaîne Cantabrique (Espagne): seul représentat du genre hors L'Amerique du Nord. Neues Jahr- buch für Geologie und Paläontologie, Monatshefte 2005(1), 46-64.

Plusquellec, Y. 2006. Révision de Hadrophyllum orbigny Milne-Edwards \& Haime, 1850 (Coelenterata, Rugosa) du Dévonien d'Amérique du Nord et discussion sur la systématique des Hadrophyllidae. Geodiversitas 28(2), 199-226.

Plusquellec, Y. \& Semenoff-Tian-Chansky, P. 1973. Révision de Combophyllum osismorum M.E. et H., 1850 (Tetracoralliaire dévonien). Bulletin du Muséum National d'Histoire Naturelle, series 3, no. 100, 411-462.

SCHRÖDER, S. 1998. Rugose Korallen und Stratigraphie des oberen Eifelium und unteren Givetium der Dollendorfer Mulde/Eifel (Mittel-Devon; Rheinisches Schiefergebirge). Courier Forschungsinstitut Senckenberg 208, 1-135.

Schröder, S. \& KazmierczaK, M. 1999. The Middle Devonian "coral reef" of Ouihlane (Morocco) - New data on the geology and rugose coral fauna. Geologica et Palaeontologica 33, 93-115.

Schuchert, C., Dall, W.H., Stanton, T.W. \& Bassler, R.S. 1905. Catalogue of the type specimens of fossil invertebrates in the Department of Geology, United States National Museum. Bulletin of the United States National Museum 53(1), 1-704.

Schulz, E. 1883. Die Eifelkalkmulde von Hillesheim. Jahrbuch Königichen Preussischen Geologiscen Landesanstalt Bergakademie Berlin Abhandlungen für 1882, 158-250.

Sмiтh, S. 1945. Upper Devonian corals of the Mackenzie River region Canada. Geological Society of America Special Paper $59,1-126$.

Sobolev, N.N. 1994. Konodonty, 93-99. In Cherkesova, S.V., Karatayute-TalitaA, V.N. \& Matukhin, R.G. (eds) Stratigrafiya i fauna nizhnedevonskikh otlozheniy tareyskogo opornogo razreza (Taymir). Nedra, Sankt-Peterburg.

Sorentino, L. 1989. Conodont assemblages spanning the Lochkovian-Pragian (Early Devonian) boundary at Eurimbla, central New South Wales. Courier Forschungsinstitut Senckenberg 117, 81-115.

Soshrina, E.D. 1936. Korally Rugosa srednego devona Severnogo Urala. Akademiya Nauk SSSR, Trudy Polyarnoy Komissii 28, 15-76.

SoshkinA, E.D. 1949. Devonskie korally Rugosa Urala. Akademiya Nauk SSSR, Trudy Paleontologicheskogo Instituta 15, $1-162$.

Soshrina, E.D. 1951. Pozdnedevonskie korally Rugosa, ikh sistematika i evolyutsiya. Akademiya Nauk SSSR, Trudy Paleontologicheskogo Instituta 34, 1-124.

Soshrina, E.D. 1952. Opredelitel' devonskikh chetyrekhluchevykh korallov. Adademiya Nauk SSSR, Trudy Paleontologicheskogo Instituta 39, 1-127.

Soshina, E.D., Dobrolyubova, T.A. \& Kabakovich, N.V. 1962. Podklass Tetracoralla. Chetyrekhluchevye korally (Rugosa), 286-356. In Sokolov, B.S. (ed.) Osnovy Paleontologii, 2. Gubki, Arkheotisiaty Kishechnopolostnye, Cherni. Izdatel'stvo Akademii Nauk SSSR, Moskva.

Soto, F. 1979. Crassicyclus n. gen. (Coelenterata, Rugosa) del Devónico de la Cordillera Cantábrica (NW de España). Trabajos de Geología, Universidad de Oviedo, España 10, 425-434. [date of imprint 1978] 
SPASSKIY, N.YA. 1955. Korally Rugosa i ikh znachenie dlya stratigrafii srednego devona zapadnogo sklona Urala. Trudy Vsesoyuznogo neftyanogo Nauchno-Issledovatel'skogo GeologoRazvedochnogo Instituta (VNIGRI), nov. ser. 90, 91-224.

SpasskiY, N.YA. 1960a. Devonskie chetyrekhluchevye korally Rudnogo Altaya. Paleontologicheskoe Obosnovanie Stratigrafii Paleozoya Rudnogo Altaya 3, 1-143.

SPASSKIY, N.YA. 1960b. O verkhney granitse eifel'skogo yarusa na Urale po faune chetyrekhluchevykh korallov. Zapiski Leningradskogo Ordenov Lenina i Trudovogo Krasnogo Znameni gornogo instituta im. G.V. Plekhanova 37(2), 83-98.

SPASSKIY, N.YA. 1977. Devonskie rugozy SSSR (sistematika, stratigraficheskoe i geograficheskoe znachenie). 344 pp. Izdatel'stvo Leningradskogo Universiteta, Leningrad.

Spasskiy, N.YA. 1983. Analiz rasprostraneniya srednedevonskikh rugoz Zakavkaz'ya, 164-170. In Dubatolov, V.N. (ed.) Nizhniy yarus srednego devona na territorii SSSR. Izdatel'stvo Nauka, Moskva.

Stauffer, C.R. 1952. The coral Microcyclus and some of its Devonian species. Geological Survey of Canada Bulletin 24, 1-33. DOI 10.4095/101525

Strusz, D.L. 1965. A note on the stratigraphy of the Devonian Garra Beds of New South Wales. Journal and Proceedings of the Royal Society of New South Wales 98(1), 85-90.

Strusz, D.L. 1968. Lower and Middle Devonian of the Molong Geanticline, New South Wales, Australia, 123-133. In Oswald, D.H. (ed.) International Symposium on the Devonian System, Calgary 1967 2. Alberta Society of Petroleum Geologists, Calgary.

STrusz, D.L. et al. 1972. Correlation of the Lower Devonian rocks of Australasia. Journal of the Geological Society of Australia 18(4), 427-455. DOI 10.1080/00167617208728782

Stumm, E.C. 1949. Revision of the families and genera of the Devonian tetracorals. Geological Society of America Memoir 40, 1-92. DOI 10.1130/MEM40-p1

Stumm, E.C. 1951-1955. Type invertebrate fossils of North America (Devonian). Unit 1-F. Tetracoralla, A cards 1-88 (1951), B cards 89-127 (1953), C cards 128-337 (1955). Wagner Free Institute of Science, Philadelphia.

Talent, J.A. \& Mawson, R. 1999. North-Eastern Molong Arch and adjacent Hill End Trough (Eastern Australia): MidPalaeozoic conodont data and implications. Abhandlungen der Geologischen Bundesanstalt 54, 49-105.

Talent, J.A., Gratsianova, R.T. \& Yolkin, E.A. 2001. Latest Silurian (Pridoli) to Middle Devonian (Givetian) of the Asia-Australia hemisphere: rationalization of brachiopod taxa and faunal lists; stratigraphic correlation chart. Courier Forschungsinstitut Senckenberg 236, 1-221.

Trotter, J.A. \& Talent, J.A. 2005. Early Devonian (midLochkovian) brachiopod, coral and conodont faunas from Manildra, New South Wales, Australia. Palaeontographica Abteilung A 273(1-2), 1-54.

TsyganKo, V.S. 1972. "Septal'nyne konusy" chetyrekhluchevykh korallov i ikh funktsional' noe znachenie. Paleontologicheskiy Zhurnal 1972(4), 31-43.

Tsyganko, V.S. 1980. O formakh rosta u Glossophyllum discoideum (Rugosa). Paleontologicheskiy Zhurnal 1980(2), 27-31.
Tsyganko, V.S. 1981. Devonskie rugozy severa Urala. 220 pp. Nauka, Leningradskoe Otdelenie, Leningrad.

Tsyganko, V.S. 2011. Devon zapadnogo sklona severa Urala i Pay-Khoya (stratigrafiya, printsipy raschleneniya, korrelyatsiya). 356 pp. Pan Uro, Ekaterinburg.

Tsyganko, V.S., Pershina, A.I., Khalymbadzha, V.G. \& Yudina, A.B. 1987. Sredniy devon Pripolyarnogo Urala (r. Shchugor), 17-27. In Tsyganko, V.S., ChermnYkH, V.A. \& Borintseva, N.A. (eds) Stratigrafiya i paleoekologiya paleozoya i kaynozoya Severo-Vostoka evropeyskoy chasti SSSR. Akademiya Nauk SSSR, Trudy Instituta Geologii Komi Nauchnogo Tsentra Uralskogo 62.

UlitinA, L.M. 1968. Devonskie korally tsistifilliny Zakavkaz'ya. Akademiya Nauk SSSR, Trudy paleontologicheskogo Instituta $113,1-99$.

Uyeno, T.T. 1978. Devonian conodont biostratigraphy of Powell Creek and adjacent areas, western District of Mackenzie, 233-257. In Stelck, C.R. \& Chatterton, B.D.E. (eds) Western and arctic Canadian biostratigraphy. Geological Association of Canada Special Paper 18.

Uyeno, T.T. \& Mason, D. 1975. New Lower and Middle Devonian conodonts from northern Canada. Journal of Paleontology 49(4), 710-723.

Uyeno, T.T., Pedder, A.E.H. \& Uyeno, T.A. 2017. Conodont biostratigraphy and T-R cycles of the Middle Devonian Hume Formation at Hume River (type locality), northern Mackenzie Mountains, Northwest Territories, Canada. Stratigraphy 14(1-4), 391-404. DOI 10.29041/strat.14.1-4.391-404

Walliser, O.H. 2000. The Eifelian-Givetian Stage boundary. Courier Forschungsinstitut Senckenberg 225, 37-47.

Walliser, O.H., Bultynck, P., Weddige, K., Becker, R.T. \& House, M.R. 1995. Definition of the Eifelian-Givetian Stage boundary. Episodes 18(3), 107-115.

WARREN, P.S. 1944. The role of Sphaerospongia tessellata in the Mackenzie River Devonian. Canadian Field-Naturalist 58(1), 28-29.

Warren, P.S. \& Stelck, C.R. 1950. Succession of Devonian faunas in western Canada. Transactions of the Royal Society of Canada 44 (section 4, series 3), 61-78.

Warren, P.S. \& Stelck, C.R. 1956. Reference fossils of Canada 1. Devonian faunas of western Canada. Geological Association of Canada Special Paper 1, 1-15.

Weddige, K. 1977. Die Conodonten der Eifel-Stufe im Typusgebiet und in benachbarten Faziesgebieten. Senckenbergiana lethaea 58(4-5), 271-419.

WedeKIND, R. 1923. Die Gliederung des Mitteldevons auf Grund von Korallen. Gesellschaft zur Beförderung der gesamten Naturwissenschaften zu Marburg, Sitzungsberichte, Jahrgang 1922, 4, 24-35.

Wedekind, R. 1924. Das Mitteldevon der Eifel. I. Teil. Die Tetrakorallen des unteren Mitteldevon. Schriften der Gesellschaft zur Beförderung der gesamten Naturwissenschaften zu Marburg 14(3), 1-93.

WeYER, D. 1973. Einige Rugose Korallen aus der Erbslochgrauwacke (Unterdevon) des Unterharzes. Zeitschrift für geologische Wissenschaften 1(1), 45-65. 
Weyer, D. 1975. Combophyllidae (Anthozoa, Rugosa) im Mitteldevon des Thüringer Schiefergebirges. Freiberger Forschungshefte C304, 7-31.

WiLson, G.A. 1989. Documentation of conodont assemblages across the Lochkovian-Pragian (Early Devonian) boundary at Wellington, central New South Wales, Australia. Courier Forschungsinstitut Senckenberg 117, 117-171.

YIN, T.H. 1938. Devonian fauna of the Pochiao shale of eastern Yunnan. Bulletin of the Geological Society of China 18(1), 33-66. DOI 10.1111/j.1755-6724.1938.mp18001003.x
Yu, C.-M., Liao, W.-H. \& Deng, Z.-Q. 1974. Devonian corals, 223-232. In Nanking Institute of Geology and Paleontology, Academia Sinica (ed.) A handbook of the stratigraphy and paleontology in southwest China. Science Press, Beijing. [in Chinese]

Zheltonogova, V.A. \& IvaniYa, V.A. 1961. Devonskaya Systema. Podklass Tetracoralla (Rugosa). Tetrakorally, 368-408. In Khalfin, L.L. (ed.) Biostratigrafiya paleozoya SayanoAltayskoy gornoy oblasti II Sredniy Paleozoy. SNIIGGIMS, Novosibirsk. [date of imprint 1960]

Appendix. GSC localities. Unless otherwise stated all material collected and identified by the present writer.

C-001800. - Hume Formation, $10.7 \mathrm{~m}$ above base of formation, Bosworth Creek, Norman Range, $65^{\circ} 16^{\prime} \mathrm{N} 126^{\circ} 50^{\prime} \mathrm{W}$. Collected with Eoschuchertella adoceta (Crickmay) etc. by W.S. MacKenzie in 1968.

C-001804. - Hume Formation, loose from $7.6 \mathrm{~m}$ of mostly covered strata at base of formation, Canyon Creek, Norman Range, $65^{\circ} 17^{\prime} \mathrm{N} 126^{\circ} 27^{\prime} \mathrm{W}$. Single specimen collected by W.S. MacKenzie in 1968.

C-002536. - Hume Formation, 54.9-59.4 m below exposed top of formation, near SW side of Sam MacRae Lake $65^{\circ} 57^{\prime} \mathrm{N} 127^{\circ} 15^{\prime} \mathrm{W}$. Collected with Eoschuchertella adoceta (Crickmay) etc. in 1968.

C-003871 and C-003872. - Hume Formation, 129.6-131.2 m above base and 2.4-4.0 $\mathrm{m}$ below top, left side of Powell Creek, Mackenzie Mountains, 65 ${ }^{\circ} 16.5^{\prime} \mathrm{N} 128^{\circ} 46^{\prime} \mathrm{W}$. Collected with Carinatrypa dysmorphostrota (Crickmay) etc. in 1969 \& 1971.

C-003959. - Hume Formation, $25.3 \mathrm{~m}$ above base, $142.4 \mathrm{~m}$ below top, Tern Creek section, $2.4 \mathrm{~km}$ NNE of Tern lake, $64^{\circ}$ $34^{\prime} \mathrm{N} 128^{\circ} 22^{\prime} \mathrm{W}$. Collected with Eoschuchertella adoceta (Crickmay) by W.S. MacKenzie in 1968.

C-012116. - Hume Formation, 19.5-25.6 m above base, 88.7-94.8 $\mathrm{m}$ below top, W fork of Prohibition Creek, $65^{\circ}$ $12.5^{\prime} \mathrm{N} 126^{\circ} 13^{\prime} \mathrm{W}$. Collected with Eoschuchertella adoceta (Crickmay) etc. in 1971.

C-012174. - Hume Formation, 124.4-125.4 $\mathrm{m}$ above base and 8.2-9.2 $\mathrm{m}$ below top, right side of an unnamed tributary of Powell Creek, Mackenzie Mountains, 65 $16.8^{\prime} \mathrm{N} 128^{\circ} 46^{\prime}$ W. Collected with Carinatrypa dysmorphostrota (Crickmay) etc. in 1971 .

C-012175. - Hume Formation, $129.0 \mathrm{~m}$ above base and $4.6 \mathrm{~m}$ below top, right side of an unnamed tributary of Powell Creek, Mackenzie Mountains, $65^{\circ} 16.7^{\prime} \mathrm{N} 128^{\circ} 46^{\prime} \mathrm{W}$. Collected in 1971.

C-024631. - Hume Formation, 15.2-17.7 m above base, 96.9$99.4 \mathrm{~m}$ below top, type section of formation on unnamed tributary of Hume River, $65^{\circ} 19.7^{\prime} \mathrm{N} 129^{\circ} 59^{\prime}$ W. Collected with Eoschuchertella adoceta (Crickmay) etc. in 1972.

C-024674. - Loose from 110.4-114.1 $\mathrm{m}$ above base and 0.6-4.3 m below top of the type section of the Hume Formation, $65^{\circ}$ $19.7^{\prime} \mathrm{N} 129^{\circ} 59^{\prime} \mathrm{W}$. Collected with Carinatrypa dysmorphostrota (Crickmay) etc. by W.S. MacKenzie in 1974.
C-025838. - Loose from 100.4-102.8 $\mathrm{m}$ above base and $0-0.24 \mathrm{~m}$ below top of Hume Formation, Gayna River gorge, Mackenzie Mountains, $65^{\circ} 24.7^{\prime} \mathrm{N} 129^{\circ} 11.2^{\prime} \mathrm{W}$. Collected in 1972.

C-025839. - Hume Formation, 7.3-9.2 m below top, left side of Bell Creek, Mackenzie Mountains, 65 $17.5^{\prime} \mathrm{N} 128^{\circ} 53.5^{\prime}$ W. Collected with Carinatrypa dysmorphostrota (Crickmay) etc. in 1979.

C-025840. - Hume Formation, 6.1-7.3 m below top, left side of Bell Creek, same section as above. Collected with Carinatrypa dysmorphostrota (Crickmay) etc. in 1979.

C-049662. - Hume Formation, 123.6-123.9 m above base and 9.7-10.0 m below top, right side of an unnamed tributary of Powell Creek, Mackenzie Mountains, 65 16.7' N $128^{\circ} 46^{\prime} \mathrm{W}$. Collected between occurrences of Carinatrypa dysmorphostrota (Crickmay) etc. in 1981.

C-049669. - Hume Formation, 6.5-7.4 m below top, left side of Mountain River at Mackenzie Mountain front, $65^{\circ} 14^{\prime} \mathrm{N}$ $128^{\circ} 34.5^{\prime} \mathrm{W}$. Collected in 1981.

C-049670. - Hume Formation, 5.1-5.4 m below top, same section as above. Collected in 1981.

C-075538 and C-075539. - Hume Formation, $27.5 \mathrm{~m}$ above base, c. $135.0 \mathrm{~m}$ below top, North Eduni 1 section, $2.4 \mathrm{~km}$ NNE of Tern Lake, 64 $37^{\prime} \mathrm{N} 129^{\circ} 53^{\prime} \mathrm{W}$. Collected with Eoschuchertella adoceta (Crickmay) by D.W. Morrow in 1977.

C-075555. Hume Formation, unrecorded level but co-occurs with Eoschuchertella adoceta (Crickmay), Arctic Red 2 section, Mackenzie Mountains, $64^{\circ} 42.5^{\prime} \mathrm{N}, 130^{\circ} 10^{\prime} \mathrm{W}$. Collected by D.W. Morrow in 1977.

C-075743. - Hume Formation, $13.5 \mathrm{~m}$ above base, $79.0 \mathrm{~m}$ below top, $1.5 \mathrm{~km} \mathrm{SW}$ of the southern tip of Drainpipe Lake, Mackenzie Mountains, $65^{\circ} 02^{\prime} \mathrm{N} 129^{\circ} 17^{\prime} \mathrm{W}$. Collected with Eoschuchertella adoceta (Crickmay) etc. by D.W. Morrow in 1977.

C-083491. - Loose from upper $6 \mathrm{~m}$ of Hume Formation, Imperial Hills, $65^{\circ} 27.5^{\prime} \mathrm{N} 128^{\circ} 40.5^{\prime} \mathrm{W}$. Collected with Carinatrypa dysmorphostrota (Crickmay) etc. in 1972.

O-007235. - Hume Formation ("Lower Ramparts Limestone" of 1942 Canol Project nomenclature), "S end Wolverine anticline", probably Bosworth Creek, Norman Range, approx. $65^{\circ} 16^{\prime} \mathrm{N} 126^{\circ} 50^{\prime} \mathrm{W}$. Collected with Eoschuchertella adoceta (Crickmay) by G.S. Hume in 1922 .

O-040357. - Hume Formation, 23.2-25.9 $\mathrm{m}$ above base, at 
least $100 \mathrm{~m}$ below top, unnamed tributary of Gayna River, Mackenzie Mountains front, $65^{\circ} 19^{\prime} \mathrm{N} 129^{\circ} 39.3^{\prime} \mathrm{W}$. Collected with Eoschuchertella adoceta (Crickmay) etc. by J.D. Aitken in 1959.

O-058665. - Headless Formation, $83.9 \mathrm{~m}$ above base and $211.8 \mathrm{~m}$ below top of formation, E-W trending ridge in NW Thundercloud Range, $62^{\circ} 42.5^{\prime} \mathrm{N} 126^{\circ} 29^{\prime} \mathrm{W}$. Collected with Eoschuchertella adoceta (Crickmay) etc. by J.A. Roddick \& P.J. Street (see Gabrielse et al. 1973, part 2, pp. 214, 215) in 1968. The stratigraphic level is at least $94.5 \mathrm{~m}$ below an occurrence of Carinatrypa dysmorphostrota (Crickmay). Genera identified by D.J. McLaren as Schuchertella and Carinatina.
O-058761. - Headless Formation, 7.6 $\mathrm{m}$ above base, $55.5 \mathrm{~m}$ below top, stream cut about $9 \mathrm{~km} \mathrm{NE}$ of $\mathrm{N}$ end of Dal Lake, $63^{\circ} 12^{\prime} \mathrm{N} 126^{\circ} 25^{\prime} \mathrm{W}$. Collected $1.5 \mathrm{~m}$ below an occurrence of Eoschuchertella adoceta (Crickmay) by H. Gabrielse in 1963.

Triad Oil Locality D15. - Hume Formation, isolated outcrop near base of formation, left bank of Anderson River, $68^{\circ} 31.7^{\prime}$ $\mathrm{N} 127^{\circ} 12.5^{\prime} \mathrm{W}$. Collected with Eoschuchertella adoceta (Crickmay) etc. in 1959. The only conodont identified by T.T. Uyeno to species level ( $0.82 \mathrm{~kg}$ dissolved) is the long-ranging (Hume \& lower Hare Indian formations) Polygnathus parawebbi Chatterton. 